\title{
Trade Credit or Bank Credit? - Lessons Learned from Hungarian Firms between 2010 and 2015*
}

\author{
Dániel Havran - Péter Kerényi - Attila Víg
}

This paper addresses the way in which trade credit was used by Hungarian firms in the period between 2010 and 2015. Relying on Burkart and Ellingsen's (2004) theory of trade credit, we use panel data on 14,554 Hungarian firms (including 68 large corporations) to estimate the relationship of trade credit and short-term bank credit. Estimated on sub-samples broken down by profitability, our results only confirm a complementary relationship. We also examine the relationship separately for each category of firm size. We found a complementary relationship for small and microenterprises, whereas the results obtained for large corporations imply a substitution effect. In Hungary, in the period after 2013 accounts payable tended to be increased by financially constrained micro and medium-sized enterprises and mostly held steady by financially unconstrained firms.

Journal of Economic Literature (JEL) codes: G32, C23

Key words: trade credit, financial constraints

\section{Introduction}

Firms consider trade credit to be an important channel of external funding, particularly in cases when they have no other access to finance. Trade credit is often a substitute for short-term bank credit, while it is also possible that access to bank credit is facilitated by the willingness of suppliers that are more familiar with the firm to finance it. Accordingly, in various stages of the business cycle, certain firms rely on trade credit more heavily, and others less so. In recent years, Hungarian

\footnotetext{
* The views expressed in this paper are those of the author(s) and do not necessarily reflect the offical view of the Magyar Nemzeti Bank.

Dániel Havran is an associate professor at the Corvinus University of Budapest.

E-mail: daniel.havran@uni-corvinus.hu

Péter Kerényi is a PhD student at the Doctoral School of Business Informatics at the Corvinus University of Budapest, and is a scholar on the Pallas Athene Domus Educationis Foundation.

E-mail: peter.kerenyi@uni-corvinus.hu

Attila Víg is a PhD student at the Doctoral School of Quantitative Economics at the Corvinus University of Budapest, and is a scholar on the Pallas Athene Domus Educationis Foundation.

E-mail: attila.vig@uni-corvinus.hu
}

The authors wish to thank Bisnode Magyarország Kft. for the data provided.

The Hungarian manuscript was received on 9 August 2017.

DOI: http://doi.org/10.25201/FER.16.4.86121 
firms experienced both a period of recession in the financing environment and the subsequent recovery. This paper is concerned with how accounts payable were used for financing purposes in the period between 2010 and 2015 by Hungarian non-financial and non-utility firms which draw up annual accounts.

For the same period, a number of studies have been produced on the trends in the funding of Hungarian firms, mostly addressing the practice of bank financing or the effect of stimulating credit supply (Funding for Growth Scheme), e.g. Csubák Fejes 2015; Bálint - Fellner 2016, 2017; Bokor - Hidasi 2014; Endrész - Harasztosi - Lieli 2015. In the literature, few analyses have been carried out on the use of trade credit in respect of the past years (Szücs 2008; Nábelek 2016). However, understanding firms' short-term financing practices could vary and complement the overall picture about long-term financing. With our paper, it is on that issue that we wish to contribute to the Hungarian discourse on corporate finance.

Our analysis has both cross-sectional and temporal aspects.

In taking a cross-sectional approach, we seek to explore whether in the period concerned, trade credit was used by firms to complement or substitute bank credit. We rely on Burkart and Ellingsen's (2004) model to establish the theoretical framework required to address this issue. To segment firms, we use indices representing firms' financial constraints - Kaplan-Zingales ${ }^{1}$, Whited-W $\mathbf{W}^{2}, \mathrm{Cleary}^{3}$ - as well as corporate profitability (low, medium and high EBIT/ASSET), in contrast to the empirical work of Cunningham (2005), who used firms' "wealth" (i.e. profit, a proxy for the size of internal or own funds) to measure the presence of financial constraints. The propositions of theory are only supported by our estimates unambiguously for small and microenterprises.

We are also interested in the extent to which the result changes according to the category of firm size. Using Hungarian data, our empirical results mostly confirm that for large and medium-sized enterprises, there is no or only weak substitution between trade credit and bank credit, whereas the relationship is complementary for small and microenterprises. We find that the presence of accounts receivable also leads to increased use of trade credit, and that the effect is the strongest in the case of financially constrained firms.

Owing to the difference in the relationship between these channels of finance, firms respond differently to cyclical changes. In the period under review, the pattern emerging in the use of trade credit may be pro-cyclical for some firms (with the volume of accounts payable falling in crisis and growing in recovery), and counter-

\footnotetext{
${ }^{1}$ Kaplan - Zingales (1997)

${ }^{2}$ Whited - Wu (2006)

${ }^{3}$ Cleary (1999)
} 
cyclical for others (with days outstanding becoming longer in crisis and shorter in recovery). Could it be argued that firms tend to accumulate payables during times of crisis? Or, conversely, do payables increase when firms use them to finance their growth during times of recovery? Industry character notwithstanding, what are the characteristics of firms in these two groups? What was the level of volatility in each case? Although less reliably in statistical terms, the empirical analysis of cyclicality has found the accumulation of payables in the recovery period to be a feature of financially constrained firms, whereas with financially unconstrained firms days payable outstanding did not increase in the period of recovery. These tendencies could mostly be shown for small and microenterprises.

The rest of this paper is structured as follows. First, an overview is offered on the general financing situation of Hungarian firms in the period between 2010 and 2015, and then a theoretical framework is established as a basis for the empirical analysis. This is followed by the presentation of data and the approach used. The Results section presents tables for the estimates obtained, with the corresponding interpretations. A brief summary is provided the end of the paper.

\section{Payables as reflected in corporate finance: $2010-2015$}

For Hungarian firms, recovery from the 2008 crisis was protracted, with the turning point arriving only in 2013/2014 after another dip in 2012. A period characterised by financial constraints and pessimistic expectations was followed by one that offered improved access to credit and a better outlook. In the following, a brief summary is provided of that period in terms of firms' financing practices. Our primary focus will be the MSME segment.

Figure 1 represents some of the trends emerging from the database we processed for the period under review. (The Bisnode database, which contains the financial accounts collected by the tax authority for all firms in scope, will be explained in detail as part of the empirical analysis.) The diagrams show the medians derived from individual ratios. 


\section{Figure 1 \\ Main trends in corporate finance, 2010-2015 \\ (median values)}
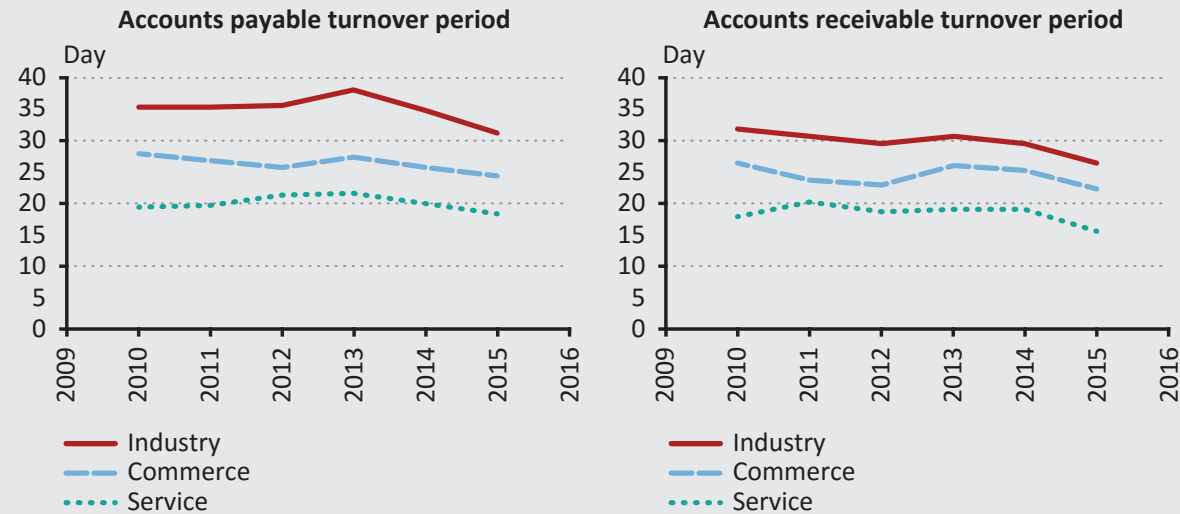

Bankloan and trade credit

Short-term funding needs

Per cent of total assets
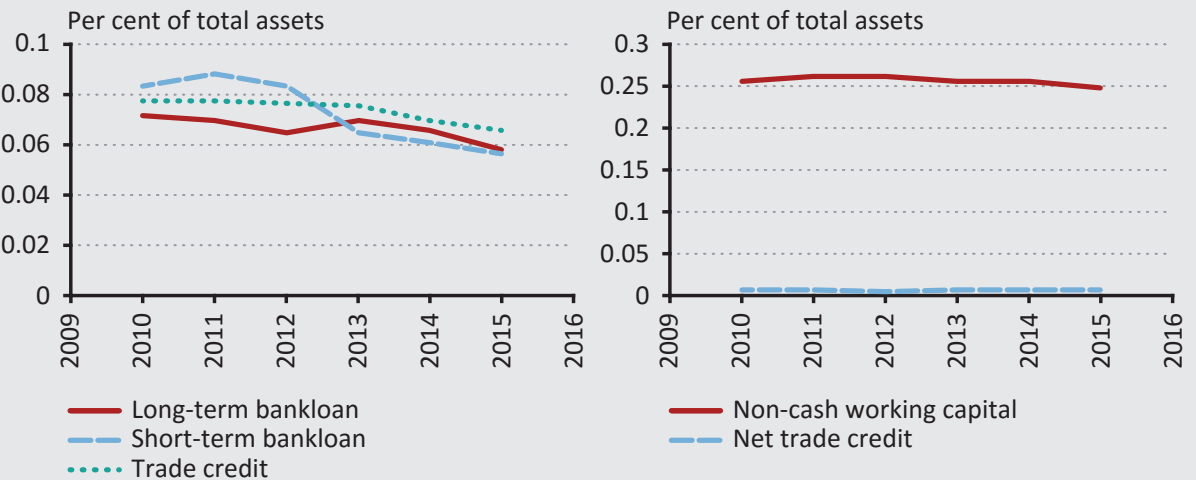

Note: The indicators represented in each diagram were derived as follows: days payable outstanding were derived as the ratio of accounts payable on year-end to material costs, multiplied by 365 , and days receivable outstanding were derived as the ratio of accounts receivable on year-end to annual sales, multiplied by 365. Short-term and long-term bank credit outstanding and accounts payable as at the end of the year were related to total assets. Net trade credit refers to accounts receivable less accounts payable, relative to total assets; and non-cash working capital refers to non-cash current assets less accounts payable, relative to total assets.

Source: Calculations based on data from Bisnode Kft.

The settlement of accounts payable took the longest in 2013 in commerce, industry and services alike. After 2013, both accounts payable and receivable days outstanding became shorter. In firms with bank loans outstanding in the period, there was a steady decline in the ratio of short-term loans to total assets. The share of long-term bank loans within the balance sheet also declined, although at a much slower rate. Relative to total assets, net non-cash working capital remained level at around 25-26 per cent, while the median of net trade credit in the sample 
stagnated at around 0 per cent. This also implies that accounts receivable frequently correlates with accounts payable, and that out of the components of net working capital, the highest financing requirement is attributable to inventories.

According to Csubák and Fejes (2014) and MNB (2015), the volume of lending to MSMEs dropped from its 2008 peak of HUF 3,896.9 billion by almost one third to HUF 2,753.3 billion in 2011, followed by an increase of some HUF 750 billion in 2012. The SAFE reports produced in the same period (SAFE 2011, 2013, 2014, 2015) show that for small and medium-sized enterprises, access to external finance was the most difficult in 2011, following which firms found their situations to be steadily improving. At the same time, finding skilled staff became increasingly difficult, while a steadily narrowing group of respondents identified market competition as the key challenge. A summary of the responses is provided in Table 1. Questionnaire responses also show that the period between 2013 and 2015 saw a decrease in the ratio of respondents that had their request for financing rejected. As the questionnaires for European countries were administered to relatively small samples in Hungary, the ratios obtained for the attitudes identified must be treated with caution.

\begin{tabular}{|c|c|c|c|c|c|}
\hline \multicolumn{6}{|l|}{$\begin{array}{l}\text { Table } 1 \\
\text { Main challenges to Hungarian SMEs } \\
\text { (SAFE questionnaire surveys) }\end{array}$} \\
\hline $\begin{array}{l}\text { Which of the following problems is the most } \\
\text { challenging for your firm? }\end{array}$ & 2009 & 2011 & 2013 & 2014 & 2015 \\
\hline Finding customers & $43.50 \%$ & $24.80 \%$ & $18.90 \%$ & $16.22 \%$ & $26.14 \%$ \\
\hline Competition in the market & $1.70 \%$ & $23.50 \%$ & $17.10 \%$ & $14.51 \%$ & $9.57 \%$ \\
\hline Access to finance & $18.70 \%$ & $22.00 \%$ & $17.30 \%$ & $14.06 \%$ & $11.29 \%$ \\
\hline Costs of labour or production & $3.10 \%$ & $6.10 \%$ & $11.90 \%$ & $10.73 \%$ & $12.37 \%$ \\
\hline Availability of skilled staff & $4.20 \%$ & $6.60 \%$ & $10.90 \%$ & $18.36 \%$ & $21.93 \%$ \\
\hline Regulatory environment & $12.40 \%$ & $10.90 \%$ & $11.20 \%$ & $14.68 \%$ & $9.33 \%$ \\
\hline Other & $16.40 \%$ & $6.10 \%$ & $12.70 \%$ & $11.44 \%$ & $9.37 \%$ \\
\hline
\end{tabular}

Source: Data from the SAFE (2011, 2013, 2014, 2015) questionnaire surveys

The MNB's reports following up on developments in lending (Bálint - Fellner 2016, 2017) also confirm the tendency perceived by firms, i.e. that the terms of bank lending to firms significantly improved from 2013 onwards. The study argues that the differential between the lending rate and the cost of funding also dropped, collateral requirements and the required level of creditworthiness were eased, and the available credit lines increased. From June 2013 onwards, subsidised loans (primarily the Funding for Growth Schemes, "FGS") played a major role in facilitating access to finance. While the main focus of FGS 1 was loan replacement, FGS 2, launched in autumn 2013, already brought about improvements in the terms of 
access to working capital and investment loans as well (FGS 3 in 2016 already falls outside of the period under review). Analyses are provided in Módos, Bokor and Hidasi (2014) and Bokor, Fellner and Plajner (2014) on the developments of the period, and in Endrész, Harasztosi and Lieli (2015) on the effect of the FGS on investment.

While financing opportunities clearly improved in 2013-2015, developments in the demand for finance appear more gloomy. Demand for finance was predominantly determined by selling opportunities and expectations of growth. The SME Survey of January 2015 by the Institute for Economic and Enterprise Research ("GVI") (Nyírö and Hajdu 2015) shows that while cyclical indicators consistently identify summer 2009 and summer 2012 as the two troughs, expectations improved considerably from 2013. Juhász and Reszegi (2017) conclude that - although the change in expectations brought back the sentiment preceding the crisis - firms remained unable to produce growth relative to pre-crisis levels. On balance, demand for finance grew once the effects of the recession were eliminated; however, that meant returning to the previous level without any additional financing requirement resulting from growth. Bálint and Fellner's (2017) report, referred to earlier, also investigated developments in credit demand. The authors explain that while demand for long-term loans dropped significantly in 2010-2013 and then increased again later, no typical trends could be identified in demand for short-term bank loans. As a combined result, between early 2010 and 2013 Q2 the growth rate of long-term corporate loans was negative in each quarter, but the situation improved from 2013 Q3, although without any significant growth yet. Even before the period under review, circular debt was common, especially in construction and among firms with a headcount below 50 employees (Szücs 2008), and this persisted even in 2016. Such debt generally qualified as past due accounts payable, and often also as bad debt from the suppliers' perspective. According to the GVI survey (Nábelek 2016), an outstanding improvement was recorded in payment discipline in 2014.

Of respondents to the SAFE (2015) survey, 21.6 per cent had used short-term bank financing (credit line, overdraft, credit card) in the preceding six months, and 44 per cent considered this channel to be relevant to their business. Leases were the second most popular form of financing, used by 14.2 per cent of respondents recently, and considered as relevant by 37.7 per cent. Collectively, subsidised bank loans and grants were used by 8.9 per cent of respondents over the period, and 29.3 per cent considered them to be relevant. Non-subsidised bank loans were used by 6.7 per cent, and other loans by 8.4 per cent of respondents on a sixmonth time horizon. Trade credit was both less used (4.3 per cent of respondents) and considered to be less relevant (13.22 per cent) than the channels mentioned previously. The use of factoring was reported by an even lower percentage. According to the MNB Financial Stability Report based on credit institution data 
(MNB 2017), finance was used for investments in tangible assets and the purchase of inventories.

Although the cited studies vary as to the precise timing of the turning point due to differences in terms of focus, the periods under review and the availability of samples, on balance access to finance improved from 2013 Q3 onwards. In the banking sector, the volume of loans disbursed increased, but at the level of individual firms there was no significant change in the ratio of long-term bank loans to total assets. Trade credit was most used in 2013. Although trade credit was not listed among the most important sources of external finance, the data suggest that it was an important factor in the operations of domestic firms.

\section{Theoretical framework}

Trade credit can have a variety of unique motivations. In Petersen and Rajan (1996), the theories seeking to identify the reasons for the use of trade credit are grouped around three motives: (1) special financing advantages (in information acquisition, in controlling the buyer, in salvaging value from existing assets); (2) price discrimination; and (3) transaction costs.

Financing advantages (1) are built on three different arguments. According to the argument based on the first, suppliers - by virtue of their relationship with their buyers - may have more extensive and more accurate information, and better monitoring opportunities compared to other lenders (Emery 1984; Smith 1987; Freixas 1993; Biais and Gollier 1997). Arguments for the supplier's bargaining power over buyers hold that the supplier's position enables it to control the buyer, or even hold it at bay, through its ability to decide on future supplies. In explanations arguing with advantages from collateral assets, current assets obtained from the supplier may be used as collateral in the event of a payment default, an opportunity that cannot be taken in the case of cash advances. In the price discrimination approach (2), the phenomenon is captured from the supplier's point of view: Schwartz (1974) construes trade credit as the supplier's pricing policy, whereas Brennan, Maksimovic and Zechner (1988) argue that suppliers apply price discrimination through their ability to set more flexible payment terms for more price-sensitive buyers. The main proponent of explanations based on transaction costs (3) is Ferris (1981), who argues that trade credit exists because payments could be settled cheaper for both buyers and suppliers if settlement only takes place periodically (e.g. monthly or quarterly).

Burkart and Ellingsen's (2004) model provides a comprehensive theoretical description of the rationale for firms to use trade credit instead of other forms of finance. The model allows firms to use both bank finance and trade credit, but with both forms of finance there is information asymmetry between the firm and the 
lender, which imposes a credit constraint. Since under the model the bank knows less about the firm than the supplier does, the firm will face stricter constraints in the course of obtaining external funding. Consequently, due to the closer relationship, the firm can use trade credit even when it no longer has access to bank credit. Another difference is that the firm will get cash in the case of bank credit, and inputs, i.e. current assets that it can use for production, in the case of trade credit. While it is easy for the firm to realise private benefits from the cash, it is more difficult to transform less liquid inputs to private benefits. One possible consequence is that given a high level of information asymmetry, it is worthwhile for a firm to acquire assets by becoming indebted to suppliers, and then to obtain bank credit on grounds of the collateralisation so established. Burkart and Ellingsen identify that scenario as the case where trade credit is able to complement bank credit.

The relationship between the two forms of external funding was investigated empirically on samples of US firms by Nilsen (2002), Canadian firms by Cunningham (2005), and Chinese firms by Ying, Guo and Yang (2014). Most of their findings are consistent with Burkart and Ellingsen's theory. Burkart and Ellingsen viewed trade credit as a source of finance that matured in 1 to 3 months but could be prolonged, and loans provided by commercial banks typically maturing in 1 to 3 years. The primary focus of the theory is therefore on short-term sources of funding. The question of how long-term bank finance is related to trade credit is addressed by Fazzari and Petersen (1993) as part of their analysis of US firms' data. The authors observe that investments in fixed assets and net working capital compete with each other for finance, which makes long-term bank credit and trade credit possible substitutes. Ferrando and Mulier (2013) find that trade credit may also be an important source of growth.

The decision between trade credit and bank credit may also be strongly influenced by how the firm's buyers are financed. Firms with the capacity to increase their accounts payable will have more room to finance their buyers for price discrimination purposes. Moreover, accounts receivable are less liquid than cash, and additional collateral may also improve the capacity to borrow from banks. For European firms, the components of trade credit were analysed by García-Teruel and Martínez-Solano (2010), whose findings, inter alia, confirmed the theory of price discrimination.

Decisions on inventories may also play a part in the use of trade credit, as shown in a theoretical model by Bougheas, Mateut and Mizen (2007), who also test their argument empirically on a sample of firms operating in the UK. Chittenden and Bragg (1997) confirm the relationship between inventory holdings and accounts payable on samples of three countries (Germany, France, UK). As regards cash 
holdings, also analysing the data of firms in the UK, Kling, Paul and Gonis (2014) find that a higher cash ratio improves access to trade credit.

For our empirical analysis, we invoke the following conclusions by Burkart and Ellingsen (2004):

1) With financially unconstrained firms that are still within their bank debt and trade credit capacities, according to the theory complementary, substitution or no relationship between short-term bank credit and trade credit may be possible.

2) With financially constrained firms beyond their capacity for bank debt, short-term bank loans and trade credit are:

a) substitutes in the case of firms that are still within their capacity for trade debt; and

b) complements in the case of firms that are beyond their capacity for trade debt.

The implications can also be extended in terms of business cycles. Where the size of bank credit is pro-cyclical over time in a firm (i.e. showing signs of constraints), trade credit would be:

- counter-cyclical in case $2 \mathrm{a}$; and

- pro-cyclical over time in case $2 \mathrm{~b}$.

Therefore, the sensitivity of trade credit to business cycles could vary according to the respective levels of the capacity constraint on trade credit and bank credit. The authors identify the wealth (own funds) available to the firm as the factor that influences whether capacity constraints are reached. Firms with a low level of own funds are constrained in their access to both bank credit and trade credit, those with a medium level of own funds only in their access to bank credit, and firms with a high level of own funds are not constrained in their access to either type of credit.

In our first analysis, we explore how accounts payable are related to short-term and long-term lending. We also address the effect of accounts receivable on accounts payable. Our second question is whether patterns that are similar to the theoretical conclusions are obtained by capturing own funds through firms' average profitability, and the constraints on bank debt in ways commonly reported in the literature (using Kaplan-Zingales, Whited-Wu and Cleary indices). In practice, the capacity for trade debt can be influenced by a number of factors in addition to internal funds. Where a firm has stronger bargaining power over its supplier, it may have much greater capacity for trade debt. Therefore, in the third step we will investigate the extent to which the relationship between bank credit and trade credit varies according to firm size. As an additional fourth step, we profile the behaviour of accounts payable over time. 


\section{Data and methodology}

The data were provided by Bisnode Magyarország $\mathrm{Kft}$. The raw database includes all Hungarian firms that use double-entry bookkeeping and submit annual accounts to the tax authority. Of that population, our analysis includes Hungarian firms that draw up their annual accounts in Hungarian forints and are neither financial firms (NACE 6400-6699) nor utility providers (NACE 3500-3799). The sample does not include firms submitting simplified annual accounts or the type of accounts provided for microenterprises. Although there is a high number of firms of the latter type, their collective size is considerably smaller than the group of firms submitting annual accounts. Consequently, the macro-weight of the dataset used may be considered significant. In cleaning the data, we filtered out firms showing economically nonsensical or erroneous items (such as negative total assets or other negative balance sheet items), and where we found missing data that could not be provided (e.g. missing P/L accounts), we also filtered out the corresponding firm/ year observations. Subsequently, the dataset used for analysis was constructed to include firms for which the database contained balance sheets and $P / L$ accounts for at least three consecutive years.

This corresponds to a total of 14,554 firms, comprised of 68 large corporations, 1,332 medium-sized enterprises, 4,354 small enterprises, and 8,800 microenterprises according to the EU sales classification. Except for financial firms and utility providers, which operate using different a business logic, our database thus includes all Hungarian firms on which the tax authority has data of adequate quality. Within the sample, large corporations account for approximately 10 per cent, mediumsized enterprises 46 per cent, small enterprises 37 per cent, and microenterprises 7 per cent of the total sales.

\begin{tabular}{l} 
Table 2 \\
\begin{tabular}{l|c|c|c|c|c|c} 
Annual number of observations by sector \\
& $\mathbf{2 0 1 0}$ & $\mathbf{2 0 1 1}$ & $\mathbf{2 0 1 2}$ & $\mathbf{2 0 1 3}$ & $\mathbf{2 0 1 4}$ & $\mathbf{2 0 1 5}$ \\
\hline Commerce & 3,190 & 3,375 & 3,547 & 3,215 & 2,918 & 1,710 \\
\hline Industry & 4,372 & 4,594 & 4,773 & 4,418 & 4,079 & 2,502 \\
\hline Services & 5,167 & 5,616 & 5,840 & 5,188 & 4,557 & 2,507 \\
\hline Total & 12,729 & 13,585 & 14,160 & 12,821 & 11,554 & 6,719 \\
\hline
\end{tabular} \\
\hline
\end{tabular}

Based on the NACE classification, the sample included 3,665 firms in commerce, 4,896 firms in industry, and 5,993 firms in services (Table 2). Except for 2015 (where the annual accounts were not available for all of the firms), the database includes data on an average of 12,000 to 13,000 firms, with a low ratio of new entries and exits. 


\begin{tabular}{|c|c|}
\hline ACCOUNTS_PAYABLE: & Accounts payable (purchases of goods and services) \\
\hline ACCOUNTS_RECEIVABLE: & Accounts receivable (goods and services) \\
\hline ST_LOANS: & Short-term loans \\
\hline LT_LOANS: & Long-term loans (for investment and development purposes) \\
\hline ASSET: & Total assets (for regression analysis, its logarithm is used: LOGASSET) \\
\hline SALES: & Net sales \\
\hline AP_SALES: & Accounts payable / Net sales \\
\hline AR_SALES: & Accounts receivable / Net sales \\
\hline EBIT_SALES: & Earnings before interest and taxes / Net sales \\
\hline ST_LOANS_SALES: & Short-term loans / Net sales \\
\hline LT_LOANS_SALES: & Long-term loans / Net sales \\
\hline LEVERAGE: & (Short-term liabilities + Long-term liabilities) / Total assets \\
\hline CURRENT: & Current assets / Short-term liabilities \\
\hline CASH_SALES: & (Cash and cash equivalents) / Net sales \\
\hline INTEREST_COV: & $\begin{array}{l}\text { Interest coverage ratio: Earnings before interest and taxes / } \\
\text { (Interest payable and similar charges + Approved dividends and profit } \\
\text { sharing) }\end{array}$ \\
\hline CAPEX_SALES: & $\begin{array}{l}\text { (Fixed assets - Depreciation) / } \\
\text { Net sales }\end{array}$ \\
\hline SALES_GROWTH: & Sales growth rate as a percentage of the previous year \\
\hline PROFIT_SALES & Profit after taxes $\mathrm{t} /$ Sales $_{\mathrm{t}-1}$ \\
\hline ROE: & Profit after taxes / Shareholders' equity $_{\mathrm{t}-1}$ \\
\hline ROIC: & $\begin{array}{l}\text { NOPLAT }_{t} / I_{\mathrm{t}-1} \text { where: NOPLAT: EBIT } \times\left(1-t_{\text {eff }}\right) \\
\text { IC: Fixed assets + Current assets }- \text { Short-term liabilities }\end{array}$ \\
\hline DIVIDEND_RATIO: & Approved dividends and profit sharing / Profit after taxes \\
\hline KZ: & $\begin{array}{l}\text { Kaplan and Zingales (1997) index for unlisted firms: } \\
\mathrm{KZ}=-1.002 \times \text { CF/ASSETS }+3.3139 \times \text { LEVERAGE }-39.368 \times \text { DIV } \\
-1.315 \times \text { CASH/ASSETS }\end{array}$ \\
\hline WW: & $\begin{array}{l}\text { Whited-Wu (2006) index: } \\
\text { WW }=-0.091 \times \text { CF/ASSETS }-0.062 \times \text { DIVIDEND_PAYER }+0.021 \times \text { LEVERAGE } \\
-0.044 \times \text { LOGASSET }+0.102 \times \text { IND_SALES_GROWTH } \\
-0.035 \times \text { SALES_GROWTH } \\
\text { where IND_SALES_GROWTH is the industry average sales growth (NACE } 2 \\
\text { digits), and DIVIDEND_PAYER is the dummy for firms paying dividends }\end{array}$ \\
\hline CLEARY: & $\begin{array}{l}\text { Cleary (1999) index: } \\
\text { CLEARY }=-0.119 \times \text { CURRENT }-1.904 \times \text { LEVERAGE }+0.001 \times \text { INTEREST_COV } \\
+1.456 \times \text { PROFIT_SALES }+2.035 \times \text { SALES_GROWTH }-0.048 \times \text { SLACK, } \\
\text { where the indicator of financial slack } \\
\text { SLACK }=(\text { Cash and cash equivalents }+0.5 \times \text { Inventories } \\
+0.7 \times(\text { Accounts receivable }- \text { Short-term liabilities })) / \text { Fixed assets }\end{array}$ \\
\hline COST_SALES & Material costs \\
\hline AP_COST_SALES: & Accounts payable / Material costs \\
\hline
\end{tabular}


Table 3 lists the short names and descriptions of the variables used in our analysis. In the international literature, it is common (cf. e.g. Petersen and Rajan 1997, Nilsen 2002, Cunningham 2005, or Bougheas, Mateut and Mizen 2007) that instead of using the AP/Sales ratio to derive the Days Payable Outstanding (AP/ COST_SALES $\times 365$ ) variable, it is used as a measure of the size of accounts payable, normalised for the size of sales. For the sake of international comparability, we have opted for the latter variable. We measured accounts payable using the "Accounts payable (purchases of goods and services)" line of the balance sheets. To identify short-term loans, we used data from the "Short-term loans" line within the "Shortterm liabilities" item of the balance sheet, disregarding the "Short-term advances" item. The item short-term loans may also include repayments due within one year on loans maturing in more than one year; to that extent, a critical approach is needed to our findings concerning short maturities. Although the item chosen does not necessarily include bank loans only, in terms of its function it aggregates short-term funds that are not from suppliers, and as such may be considered as an alternative to trade credit.

With one indicator group (AP_SALES, AR_SALES, CASH_SALES, ST_LOANS_SALES, LT_LOANS_SALES, SALES_GROWTH, AP/COST_SALES) we winsorised the upper 1 per cent, whereas in other cases (EBIT_SALES, PROFIT_SALES, CAPEX_SALES, ROIC) this was done for both the lower and upper 1 per cent. With more special variables we applied different rules, e.g. COVERAGE_RATIO (20\%; 70\%), INTEREST_COV (20\%; $70 \%)$, SLACK (5\%; 90\%), ROE (8\%; 90\%).

We summarised the descriptive statistics on the most important variables in the database in Table 4. In Panel A, we considered data for the entire 2010-2015 period, while Panel B only contains data for 2011-2015, because with several calculated ratios the denominator contains a value for 2010. In the sample, the median of accounts payable was approximately HUF 16 million, and that of accounts payable was HUF 20.5 million. More than one third of the firms had short-term bank debt, and a smaller percentage had long-term bank debt. The median of total assets was HUF 385 million in the sample. The median of the AP/Sales ratio was 5 per cent, and that of the AR/Sales around 8.4 per cent. 


\begin{tabular}{|c|c|c|c|c|c|c|c|c|}
\hline \multicolumn{9}{|l|}{$\begin{array}{l}\text { Table } 4 \\
\text { Summary statistics }\end{array}$} \\
\hline \multicolumn{9}{|c|}{ Panel A: Key items } \\
\hline (HUF thousands) & $\mathrm{N}$ & Mean & St. Dev. & Min & Pctl(25) & Median & Pctl(75) & Max \\
\hline ACCOUNTS_PAYABLE & 71,568 & 105,172 & 228,182 & 0 & 694 & 15,916 & 98,422 & $2,138,715$ \\
\hline ACCOUNTS_RECEIVABLE & 71,568 & 154,412 & 404,037 & 0 & 976 & 20,588 & 139,871 & $16,552,101$ \\
\hline ST_LOANS & 71,568 & 75,464 & 390,532 & 0 & 0 & 0 & 17,542 & $15,724,355$ \\
\hline LT_LOANS & 71,568 & 26,932 & 142,189 & 0 & 0 & 0 & 0 & $2,146,469$ \\
\hline ASSET & 71,568 & $1,254,481$ & $7,441,845$ & 1 & 51,983 & 385,357 & $1,172,100$ & $1,240,000,000$ \\
\hline SALES & 71,568 & $1,220,289$ & $2,762,188$ & 101 & 35,276 & 332,765 & $1,300,015$ & $111,000,000$ \\
\hline
\end{tabular}

\begin{tabular}{l|c|c|c|c|c|c|c|c}
\hline \multicolumn{7}{c}{ Panel B: Indicators describing operations } \\
\hline Ratios & $\mathbf{N}$ & Mean & St. Dev. & Min & Pct|(25) & Median & Pct|(75) & Max \\
\hline AP_SALES & 57,014 & 0.139 & 0.352 & 0.000 & 0.010 & 0.050 & 0.127 & 2.838 \\
\hline AR_SALES & 57,014 & 0.154 & 0.258 & 0.000 & 0.016 & 0.084 & 0.182 & 1.805 \\
\hline EBIT_SALES & 57,014 & -0.053 & 0.747 & -5.643 & 0.000 & 0.035 & 0.111 & 0.964 \\
\hline ST_LOANS_SALES & 57,014 & 0.074 & 0.263 & 0.000 & 0.000 & 0.000 & 0.033 & 2.126 \\
\hline LT_LOANS_SALES & 57,014 & 0.049 & 0.270 & 0.000 & 0.000 & 0.000 & 0.000 & 2.362 \\
\hline LEVERAGE & 57,014 & 0.488 & 0.302 & 0.000 & 0.232 & 0.473 & 0.734 & 0.989 \\
\hline CURRENT & 57,014 & 3.555 & 5.388 & 0.000 & 0.960 & 1.538 & 3.109 & 22.548 \\
\hline CASH_SALES & 57,014 & 0.352 & 1.081 & 0.000 & 0.017 & 0.066 & 0.220 & 8.546 \\
\hline INTEREST_COV & 57,014 & 4.753 & 12.281 & -14.587 & 0.007 & 1.865 & 21.187 & 22.445 \\
\hline CAPEX_SALES & 57,014 & 0.074 & 0.408 & -1.653 & 0.000 & 0.012 & 0.058 & 2.777 \\
\hline SALES_GROWTH & 57,014 & 0.186 & 0.958 & -1.000 & -0.119 & 0.028 & 0.200 & 7.063 \\
\hline ROE & 57,014 & 0.155 & 0.521 & -0.907 & 0.002 & 0.085 & 0.316 & 1.201 \\
\hline ROIC & 57,014 & 0.247 & 1.302 & -4.487 & -0.000 & 0.076 & 0.256 & 8.685 \\
\hline
\end{tabular}

In empirical literature on corporate finance, the variables measuring the presence of financial constraints are compared by Farre-Mensa and Ljungqvist (2014) and Elsas and Klepsch (2016). Of the variables used by the authors, we measure the presence of constraints on access to short-term bank credit against the three most common variables: the Kaplan-Zingales, the Whited-Wu and the Cleary indices for unlisted firms. We define the presence of financial constraints based on the statistical procedures summarised in Farre-Mensa and Ljungqvist (2014). The Kaplan-Zingales and Whited-Wu indices and the Cleary index multiplied by minus one are arranged in ascending order, and then observations above the upper $30^{\text {th }}$ percentile are defined as unconstrained, and those below the lower $30^{\text {th }}$ percentile are defined as constrained. Items in the middle 40 per cent belong to neither class and are considered as representing a grey zone. We applied this procedure and the sorting to the entire sample and to the entire firm/year observation. This means 
that the classification of certain firms may change over the year, but change is not characteristic of the sample. The three classifications are compared in Table 5. Except for large corporations, the Kaplan-Zingales approach can be used to classify firms more or less independently of firm size. With large firms, the share of firms at the limit of their capacity constraints is about 50 per cent, which indicates the poor reliability of the KZ procedure (in their original paper, Kaplan and Zingales (1997) used a relatively homogeneous sample to estimate the index for categories based on self-assessment). The Cleary procedure has a moderate tendency, while the Whited-Wu procedure has a strong tendency to classify smaller firms, particularly microenterprises, as financially constrained. It is to be noted that these procedures are also not considered to be perfect alternatives in the international literature, which is why we use several classifications for our analyses.

\begin{tabular}{|c|c|c|c|c|c|c|c|c|c|c|c|c|}
\hline \multicolumn{13}{|c|}{$\begin{array}{l}\text { Table } 5 \\
\text { Classification of financial constraint measures }\end{array}$} \\
\hline \multirow[b]{2}{*}{ Size } & \multirow[b]{2}{*}{ Year } & \multirow[b]{2}{*}{$\begin{array}{l}\text { Number } \\
\text { of firms }\end{array}$} & \multicolumn{10}{|c|}{ Number of financially constrained firms in each classification } \\
\hline & & & KZ & CLEARY & WW & $\begin{array}{l}\text { KZ \& } \\
\text { CLEARY }\end{array}$ & $\begin{array}{l}\text { KZ \& } \\
\text { WW }\end{array}$ & $\begin{array}{l}\text { CLEARY } \\
\& W W\end{array}$ & $\begin{array}{c}\text { All } \\
\text { three }\end{array}$ & KZ / All & $\begin{array}{c}\text { CLEARY } \\
\text { / All }\end{array}$ & $\begin{array}{l}\text { WW / } \\
\text { All }\end{array}$ \\
\hline Large & 2011 & 68 & 39 & 5 & 0 & 3 & 0 & 0 & 0 & $57 \%$ & $7 \%$ & $0 \%$ \\
\hline Large & 2012 & 68 & 35 & 5 & 1 & 2 & 1 & 1 & 1 & $51 \%$ & $7 \%$ & $1 \%$ \\
\hline Large & 2013 & 67 & 30 & 8 & 1 & 3 & 1 & 1 & 1 & $45 \%$ & $12 \%$ & $1 \%$ \\
\hline Large & 2014 & 67 & 34 & 6 & 0 & 2 & 0 & 0 & 0 & $51 \%$ & $9 \%$ & $0 \%$ \\
\hline Large & 2015 & 34 & 14 & 6 & 1 & 1 & 0 & 1 & 0 & $41 \%$ & $18 \%$ & $3 \%$ \\
\hline Medium & 2011 & 1,269 & 434 & 143 & 5 & 63 & 5 & 0 & 0 & $34 \%$ & $11 \%$ & $0 \%$ \\
\hline Medium & 2012 & 1,310 & 431 & 181 & 11 & 80 & 9 & 7 & 5 & $33 \%$ & $14 \%$ & $1 \%$ \\
\hline Medium & 2013 & 1,298 & 416 & 195 & 15 & 79 & 11 & 12 & 9 & $32 \%$ & $15 \%$ & $1 \%$ \\
\hline Medium & 2014 & 1,254 & 365 & 192 & 18 & 64 & 13 & 12 & 9 & $29 \%$ & $15 \%$ & $1 \%$ \\
\hline Medium & 2015 & 734 & 184 & 128 & 9 & 43 & 6 & 9 & 6 & $25 \%$ & $17 \%$ & $1 \%$ \\
\hline Small & 2011 & 3,966 & 1,177 & 698 & 110 & 317 & 72 & 50 & 32 & $30 \%$ & $18 \%$ & $3 \%$ \\
\hline Small & 2012 & 4,201 & 1,233 & 867 & 121 & 353 & 86 & 74 & 49 & $29 \%$ & $21 \%$ & $3 \%$ \\
\hline Small & 2013 & 4,168 & 1,150 & 864 & 134 & 369 & 92 & 103 & 68 & $28 \%$ & $21 \%$ & $3 \%$ \\
\hline Small & 2014 & 3,967 & 1,041 & 818 & 131 & 324 & 86 & 90 & 57 & $26 \%$ & $21 \%$ & $3 \%$ \\
\hline Small & 2015 & 2,333 & 498 & 494 & 72 & 160 & 47 & 57 & 35 & $21 \%$ & $21 \%$ & $3 \%$ \\
\hline Micro & 2011 & 8,282 & 2,497 & 2,791 & 4,110 & 1,085 & 1,538 & 1,827 & 656 & $30 \%$ & $34 \%$ & $50 \%$ \\
\hline Micro & 2012 & 8,581 & 2,735 & 3,273 & 4,392 & 1,200 & 1,684 & 2,164 & 799 & $32 \%$ & $38 \%$ & $51 \%$ \\
\hline Micro & 2013 & 7,288 & 2,179 & 2,706 & 3,448 & 957 & 1264 & 1,659 & 576 & $30 \%$ & $37 \%$ & $47 \%$ \\
\hline Micro & 2014 & 6,266 & 1,758 & 2,311 & 2,873 & 773 & 976 & 1,390 & 446 & $28 \%$ & $37 \%$ & $46 \%$ \\
\hline Micro & 2015 & 3,618 & 854 & 1,413 & 1,652 & 388 & 477 & 888 & 240 & $24 \%$ & $39 \%$ & $46 \%$ \\
\hline
\end{tabular}


In the first analysis, we examine how accounts payable are related to short-term and long-term bank loans and generally to accounts receivable under constrained access to bank finance. For that purpose, the following regression equations are estimated:

$$
\begin{aligned}
& \text { AP/SALES }=\text { ST_LOANS } / \text { SALES }+ \text { LT_LOANS } / \text { SALES }+ \text { AR/SALES + } \\
& \text { + controls + Firm FE + Year FE } \\
& \text { AP/SALES }=\text { ST_LOANS } / \text { SALES }+ \text { LT_LOANS } / \text { SALES + AR/SALES + } \\
& \text { + FINC_Dummy + FINC_Dummy } \times \text { ST_LOANS/SALES + } \\
& + \text { controls + Firm FE + Year FE } \\
& \text { AP/SALES }=\text { ST_LOANS/SALES + LT_LOANS } / \text { SALES }+ \text { AR/SALES + } \\
& \text { + FINC_Dummy + FINC_Dummy } \times \text { LT_LOANS/SALES + } \\
& + \text { controls + Firm FE + Year FE } \\
& \text { AP/SALES }=\text { ST_LOANS/SALES + LT_LOANS/SALES + AR/SALES + } \\
& \text { + FINC_Dummy + FINC_Dummy } \times \text { AR/SALES + } \\
& + \text { controls + Firm FE + Year FE }
\end{aligned}
$$

where FINC_Dummy (financially constrained) is the indicator variable for financially constrained firms beyond their capacity for bank debt. Firm FE indicates firm fixed effects, and Year FE the time fixed effects. The control variables include all variables that, in addition to the effects in individual firms, adequately capture individual operational and growth characteristics: firm size $(\log ($ ASSET)), operating margin (EBIT_SALES), profitability (ROE), interest coverage ratio (INTEREST_COV), leverage ratio (LEVERAGE) lagged, liquidity ratio (CURRENT) lagged, cash to sales ratio (CASH_ SALES) lagged, capital expenditures to sales (CAPEX_SALES) lagged, dividend ratio (DIVIDEND_RATIO), sales growth (SALES_GROWTH).

The first idea for constructing Equation (1A) came from Cunningham (2005), but we use different set of base and control variables. Equation (1B) explores the relationship of accounts payable and long-term credit in order to determine whether firms increase their long-term credit by increasing trade credit. Equation (1C) is not derived from the theoretical model, but is based rather on practical considerations. In this case, we seek to determine whether in cases with higher $A R /$ Sales ratios firms pass financing on to their suppliers.

In the second analysis, we also examine access to trade credit. In the theoretical model, Burkart and Ellingsen (2004) consider the wealth of the firm to determine the finance option in terms of which the firm will become constrained. In the case of high wealth, firms are less reliant on external funds, and neither constraint applies. In the case of medium wealth, they exploit their capacities for bank debt, but not 
that for trade debt. In the case of low wealth, they are strongly reliant on external funds, and as such face constraint in both forms. As firms' wealth is difficult to observe, average profitability (EBIT/ASSET, i.e. Earnings before interest and taxes to Total assets) is used as a proxy for wealth, the rationale being that a highly profitable firm has the ability to utilise internal funds. We divide the database into three sub-samples according to low ( $<0$ per cent), medium (0-14 per cent) and high (>14 per cent) business profitability based on the firms' average EBIT/ASSET ratios. On the sub-samples, of the previous model specifications we run (1A) for the three constraint indicators, of which we use only the indicator variable for firms constrained in their access to bank finance, and consider the control group as including both the grey zone and firms unconstrained in their access to bank credit.

In our third analysis, we seek to determine the extent to which firm size influences the relationship between trade credit and short-term bank credit. In the case of US firms, Nilsen (2002) found firm size to be the factor that adequately captured access, although he did not carry out his analyses on micro-level panel data. We re-estimate our previous Equations (1) and (1A) for four sub-samples, i.e. the groups of large, medium, small and microenterprises, using the criteria for sales (EUR 50 million, EUR 10 million, and EUR 2 million, respectively; assuming an exchange rate of EUR/HUF 300) from the size definitions commonly applied to Hungarian firms. In a supplier-buyer relationship, larger size may give a firm more bargaining power over its supplier, as a result of which larger firms rarely face strict supplier constraints. Primarily, we seek to determine the extent to which this relationship is captured by firm size, but exploring the differences between firms of various sizes could in itself also produce noteworthy findings. For that purpose, the previously constructed Equation ( $1 \mathrm{~A})$ is again estimated with the three constraint dummies.

The fourth analysis quantifies the sensitivity of trade credit to business cycles. For each sub-sample (segmented by size), the following regression equation is used to obtain a direct estimate of days payable outstanding:

$$
\begin{gathered}
\text { AP/COST_SALES } \times 365=\text { AR/SALES } \times 365+\text { ST_LOANS/SALES }+ \text { LT_LOANS/SALES + } \\
+ \text { FINC_Dummy + FINU_Dummy }+\sum_{t=1}^{4} \text { YEAR_Dummy }+ \\
+\sum_{t=1}^{4} Y E A R \_D u m m y_{t} \times \text { FINC_Dummy }+ \\
+\sum_{t=1}^{4} Y E A R \_ \text {Dummy }+ \\
\times \text { FINU_Dummy }+ \\
+ \text { controls }+ \text { Firm FE }
\end{gathered}
$$


where the dummies FINC and FINU (financially unconstrained) do not cover the entire sample, given that 40 per cent of it falls into the grey zone. From the estimate, we seek to establish time fixed effects and the interactions with those effects. In other words, we seek to determine the developments in days payable outstanding, solely attributable to cyclical effects and other things being equal, for the segments of firms with varying access to finance, assuming their capacities for bank debt to be exploited. For this purpose, we multiply the dependent variable by 365 days in order to construe the result in terms of days. As regards the COST_SALES variable, we also had to take into account the fact that not all firms follow the same logic in calculating the effect of the cost of sales on profits. Some of the firms submitted P/L accounts on a total cost basis, and others on a turnover basis. The base which, if not settled immediately, could become accounts payable, was the sum of materials and consumables and contracted services in the first case, and the sum of the cost of goods sold and the value of services sold in the second case. Both types of reporting included the item of material costs, which differed from the sum calculated using the two methods in fewer than 1 per cent of all cases, and even then the difference was small.

Regressions were estimated with the fixed effects within panel method, where unique firm fixed effects were filtered using the within estimator, and time (year) effects using dummy variables. The panels are unbalanced because it was possible for the firms observed to be included in the sample for less than five years. Both the Breusch-Pagan and the Honda LM test rejected the null hypothesis that the time effect was not significant in the regressions. Unique (firm) effects were also mostly significant. The Hausmann tests run for the estimates supported the use of fixed effects versus random effects. The error terms of the estimated models implied heteroscedasticity, but in the error terms autocorrelation was not significant for four observation years. Consequently, we used White's heteroscedasticity-consistent standard errors for our statistical tests.

\section{Results}

The estimation results for the first question of our analysis (Equations (1), (1A), (1B) and (1C)) are summarised in Table 6, where the coefficients of the basic equation are shown in the first column, followed by the three equations with the constraint indicators derived using classifications based on the Kaplan-Zingales, Whited-Wu and Cleary indices. The dependent variable is the ratio of accounts payable to sales, which is reported as multiplied by 100 to ensure the readability of the coefficients. 


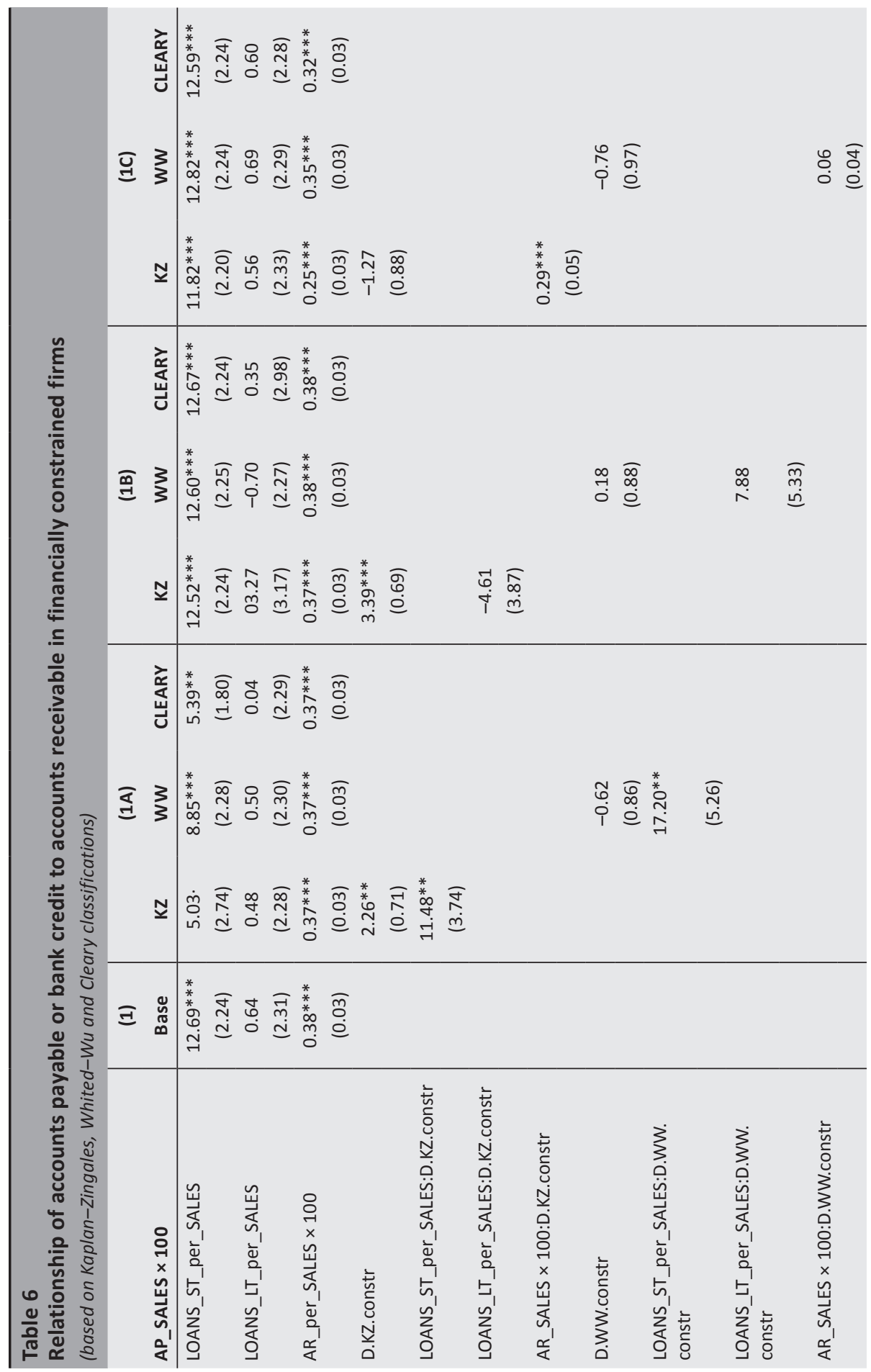




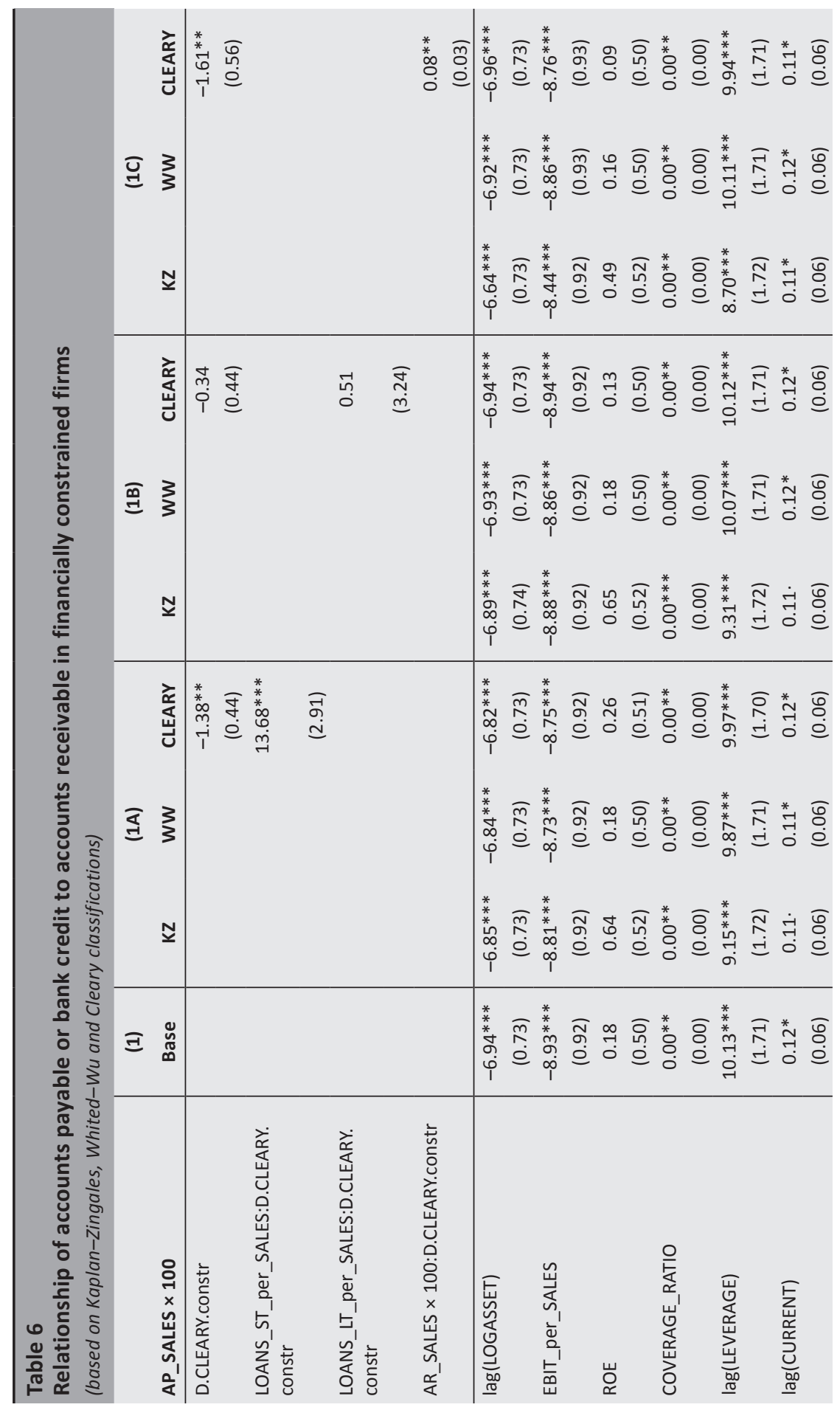




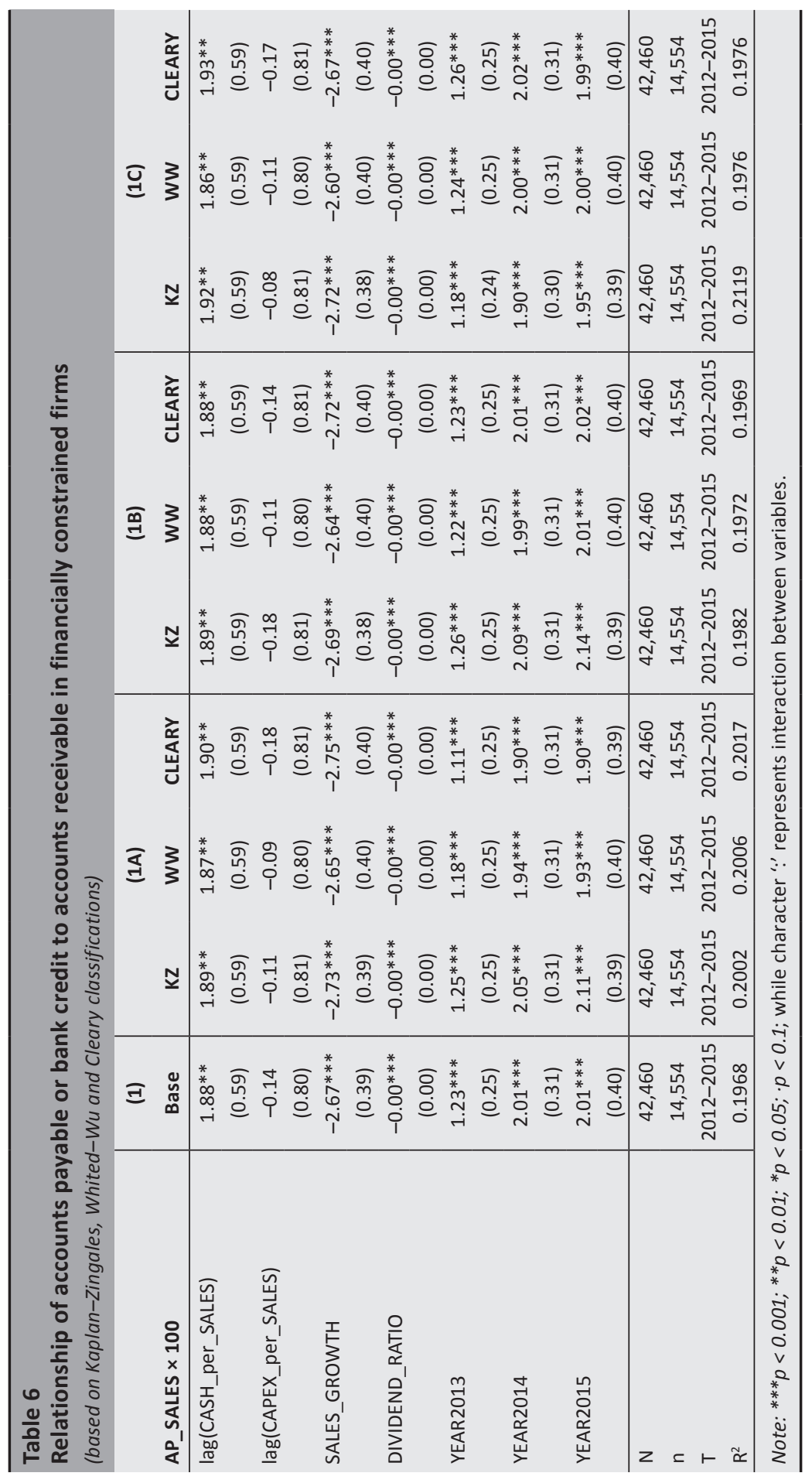


Based on an overview of the table, we find that the level of accounts payable was increased by the presence of bank credit in all estimates, which is implied by the significantly positive ST_LOAN_SALES coefficients. Due to the specific nature of the within estimator, R-square values are low, but overall the variables significantly explain the ratio of accounts payable with a 1 per cent threshold for each of the regression equations.

In the estimate for the basic equation, with firms where the ratio of short-term loans to sales was 10 percentage points (0.1) higher, the ratio of accounts payable was also 1.269 percentage points higher on average. This essentially suggests that if Burkart and Ellingsen's theoretical model is assumed to be correct, and this kind of complementarity is observed in low-wealth firms that are constrained in their access to both trade credit and bank credit, then according to the authors' theory most Hungarian firms are financially constrained. This could also mean that the credit constraint indicators introduced capture the extent of the capacity constraint rather than the fact of its presence.

A brief overview of the coefficients obtained for the control variables is also appropriate. We found that larger firms and those working with higher profit margins have a lower average AP-to-sales ratio. The ROE indicator, as a measure of profitability, failed to significantly explain the size of accounts payable, while the coefficient of the dividend ratio showed zero effect. For firms with a higher level of indebtedness, we found higher accounts payable in the following year. The AP-to-sales ratio was observed to be higher for firms with higher cash ratios, and lower for firms with higher growth rates. All of this is not contrary to general business intuition.

Financial constraint indicators did not produce consistent results in every case. Other than the above argument, this could also result from the differences in constructing the indicators, as well as from the fact that the indices used for classification were constructed on US data, while differences in the firms' operations may also undermine the reliability of application. Consequently, we only consider estimation results as robust where all three indicators produced similar results. Note that in interpreting our results, we refer to firms as constrained where the value of bank credit is one, and unconstrained where the value is zero (grey zone and firms marked as unconstrained above the $30^{\text {th }}$ percentile collectively).

In analysing Equations (1A), we essentially found short-term loans and accounts payable to be complementary. In themselves, constraint dummy indicators produced mostly insignificant or inconsistent results, but interactions were significant and combined effects (with an average volume of short-term loans) also imply complementarity. 
In the case of Equations (1B), no correlation was found between long-term credit and accounts payable: estimating for the entire sample, there is no evidence of any relationship between taking out additional long-term loans and the use of accounts payable.

Estimates for Equations (1C) show that in financially unconstrained firms, an increase in accounts receivable in a given year will be accompanied by a higher ratio of trade credit. On the entire sample, for financially constrained firms combined effects are both insignificant and contradictory. This implies that the ability of firms to pass financing on to their suppliers may depend on sector, size and other factors. 


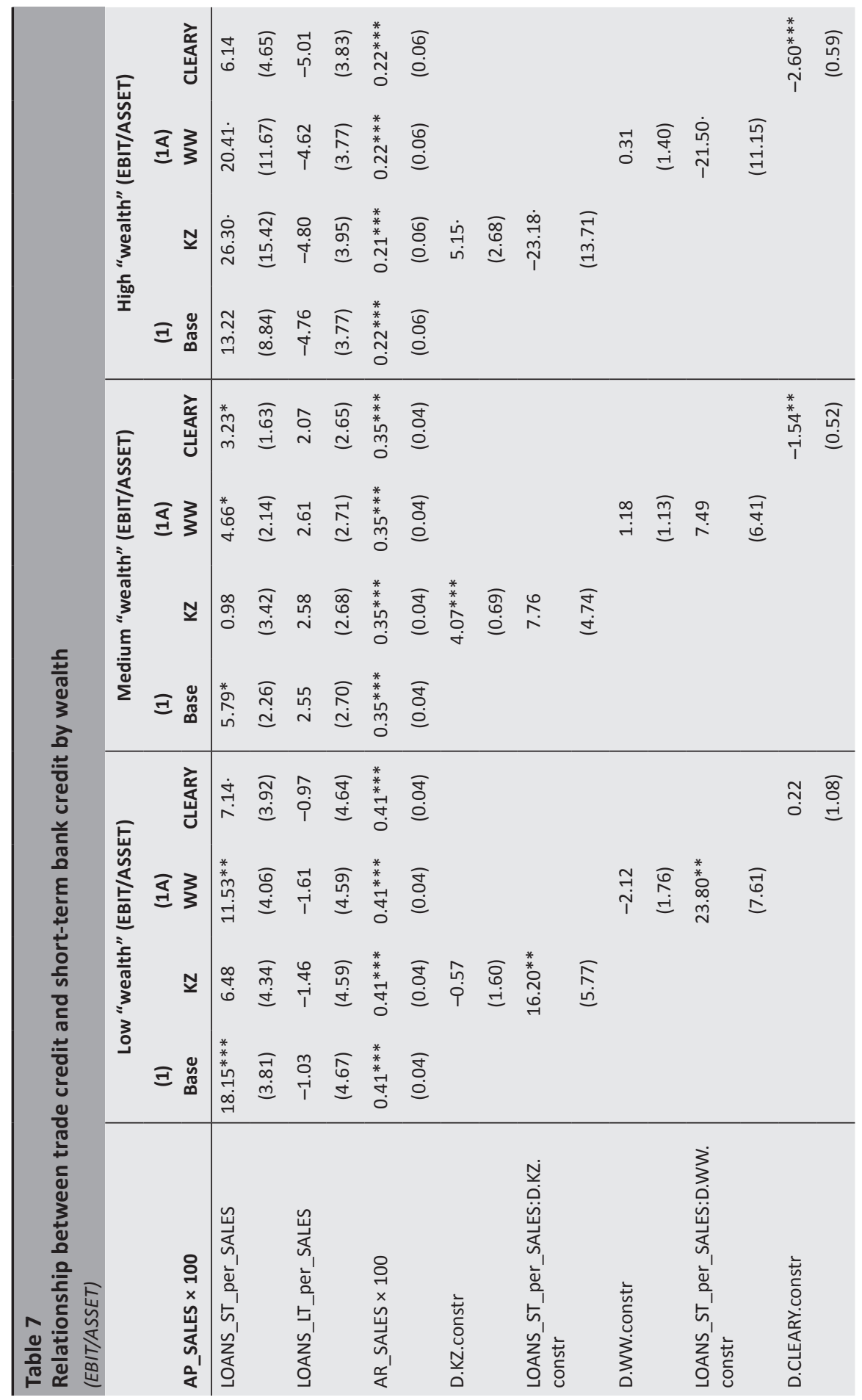




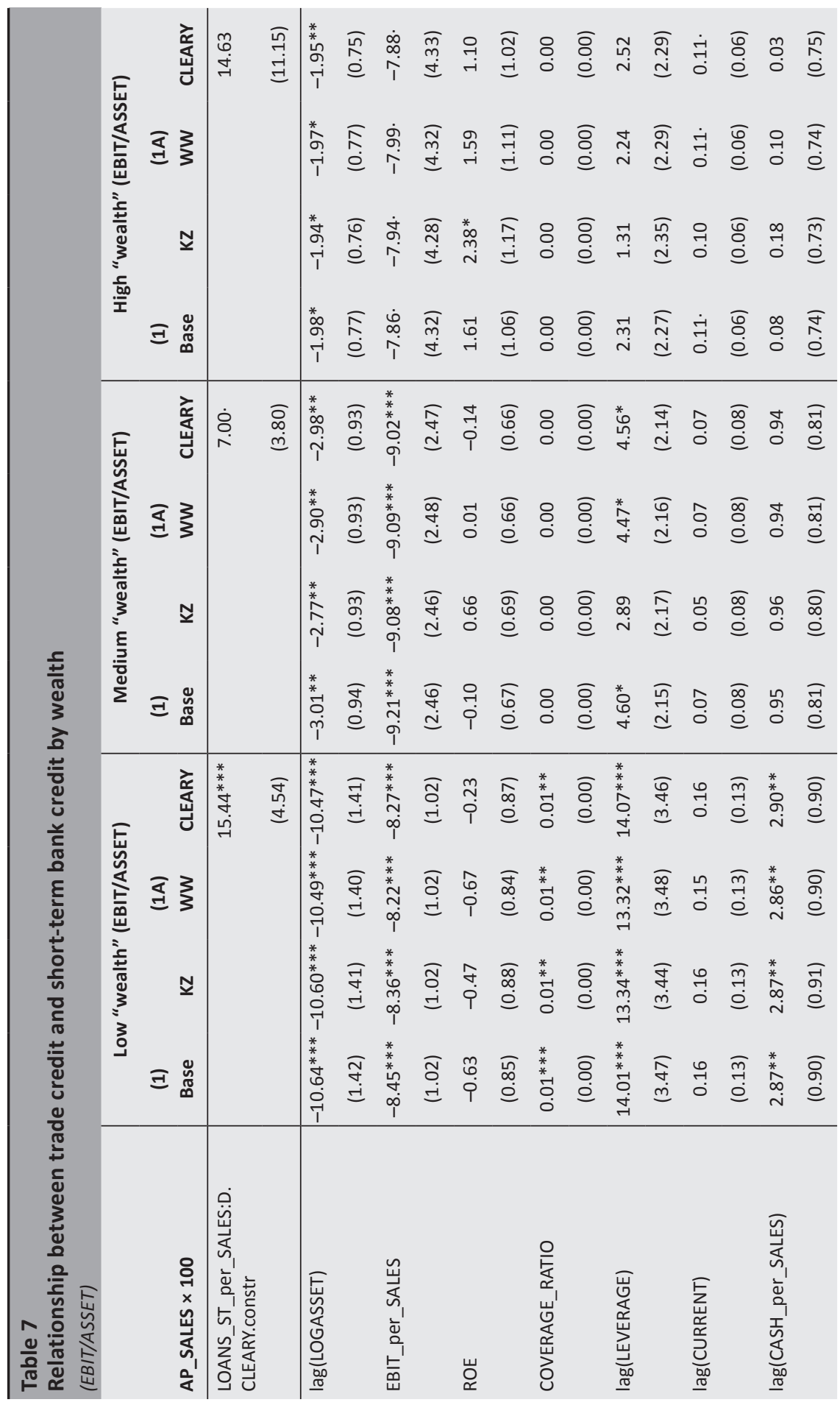




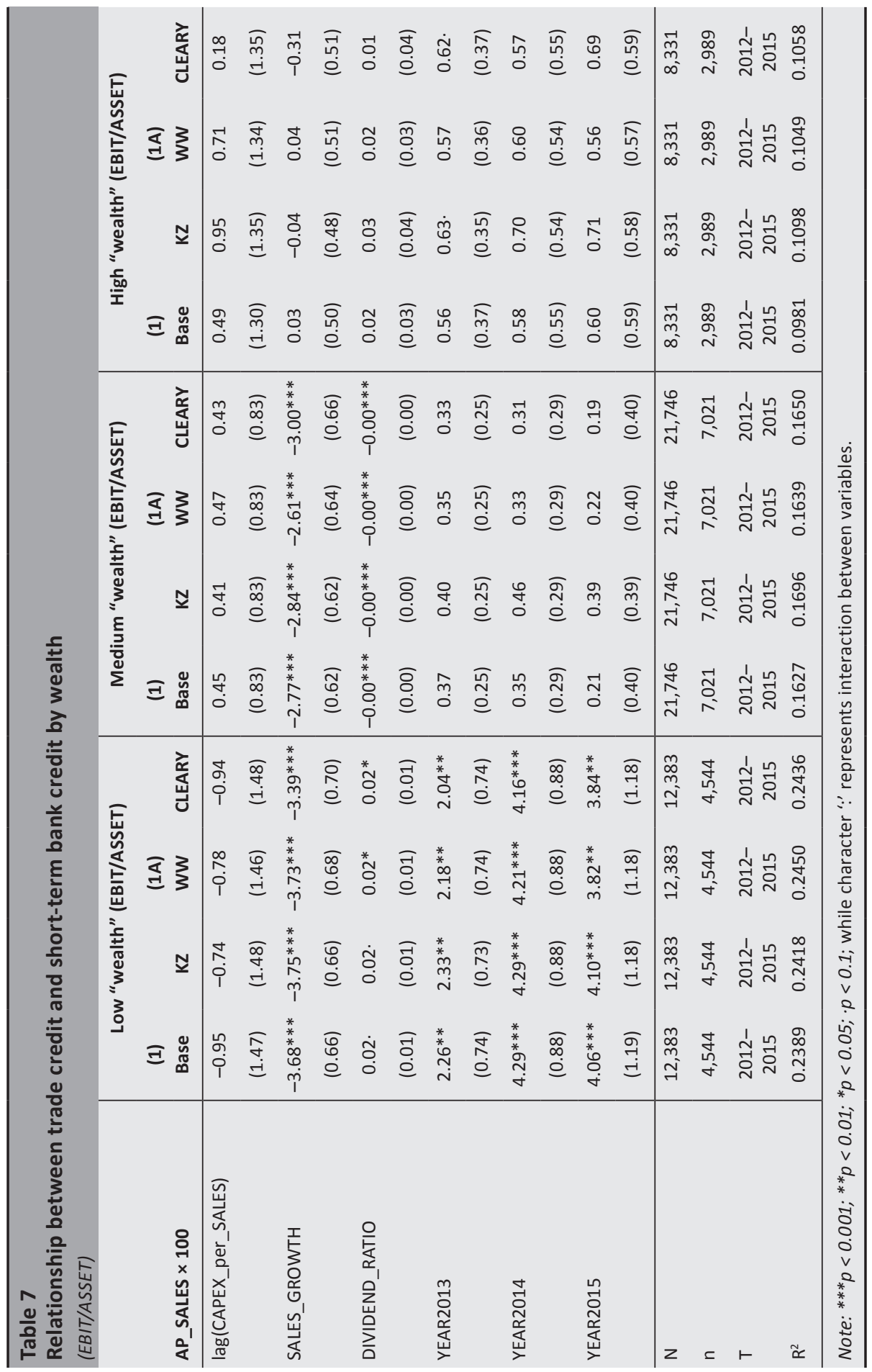


The results of the second analysis are summarised in Table 7. We estimated Equations (1) and ( $1 \mathrm{~A}$ ) on three sub-samples. These included firms (a) with negative average EBIT/ASSET ratios (representing the lower 26.6 per cent of the sample); (b) ratios between 0 and 14 per cent; and (c) ratios above 14 per cent (representing the upper 18.7 per cent of the sample). The selection of the thresholds was determined by the fact that firms with average negative performance are adequately described by Burkart and Ellingsen's low wealth, while the average 14 per cent threshold was supported by the tendency that in business practice, a higher level of profitability already enables firms to raise internal funds, and the fact that the number of items in the sub-sample is not very low either.

The propositions of Burkart and Ellingsen's model are only partially confirmed by our empirical results. In the first sub-sample, we are able to confirm the predicted complementarity. In this subsample, according to the theory, constraints apply in terms of both trade credit and bank credit, which is why a breakdown of the analysis by KZ, WW and Cleary-based indicators would not make any sense. Nevertheless, these indicators, constructed on the basis of other theories, will classify firms as both constrained and unconstrained even in this range. In such cases, the indicators are construed as suggesting that it is difficult for all participants to access bank credit due to their low profitability, and the capacity constraint actually even more applies to firms that are also marked by the indices. This will make short-term loans and accounts payable complements on the sub-sample: a higher ratio of loans will be accompanied by higher accounts payable; however, the result is only robust for severely constrained firms where the combined effects also include interactions. The second sub-sample shows barely significant complementarity in Equation (1). In such a case, for constrained firms the theoretical model would predict substitution, but we found none. We consider it plausible that under Burkart and Ellingsen's theory this falls in the category of low wealth, which explains the complementarity found. In the third sub-sample, that of highly profitable firms, we found no correlation at a significance level of 0.05 , and neither is correlation predicted according to the theory. If we accept that we were overly lenient in selecting the wealth threshold, then zero effect could mean that the sub-sample includes firms characterised by substitution as well as firms characterised by complementarity. By way of comparison to research carried out on Canadian data for similar purposes, Cunningham (2005) did not succeed in identifying the third category, but did identify complementarity in the first category and then substitution in the second. 


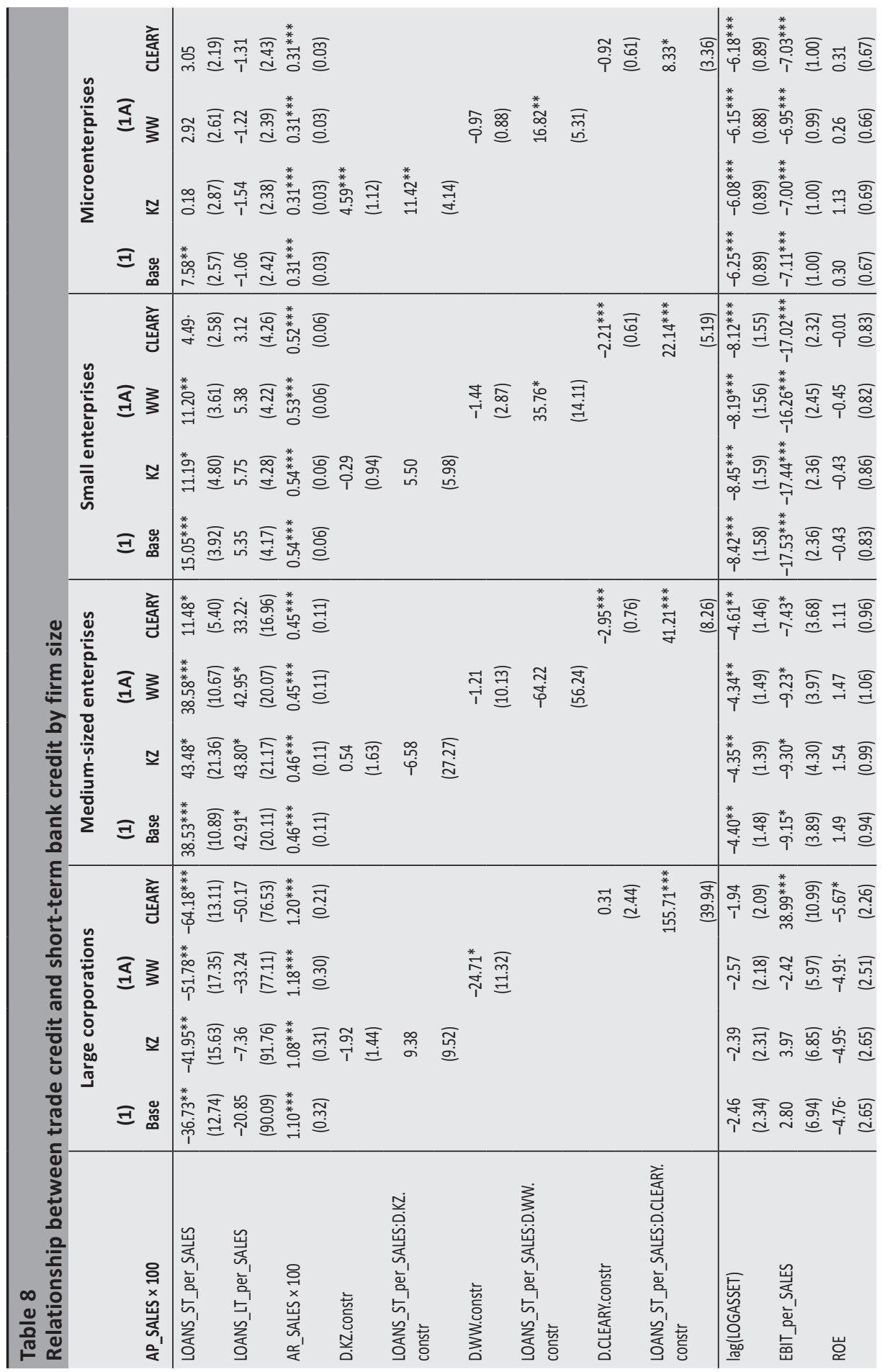


䇋 *

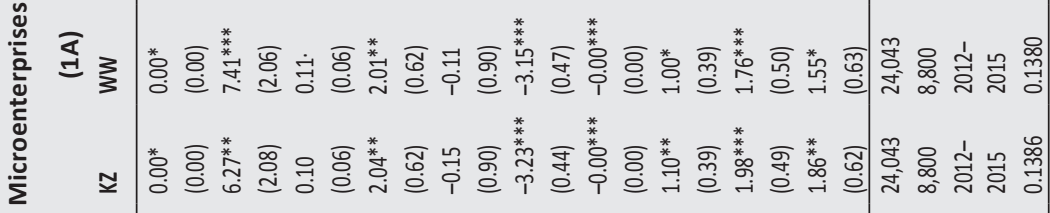
三

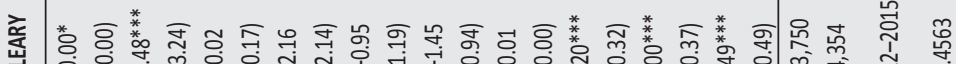

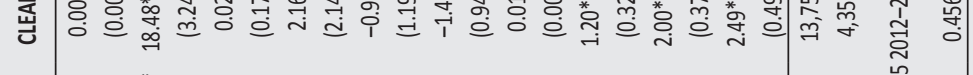

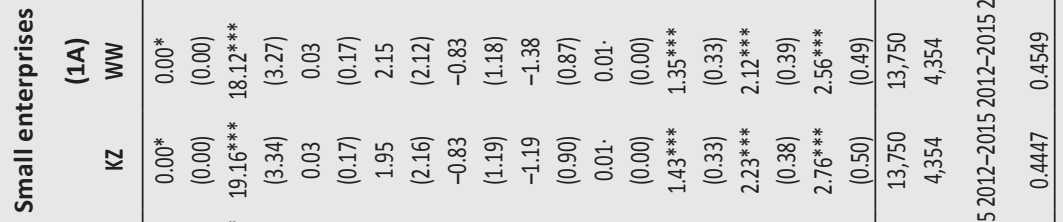

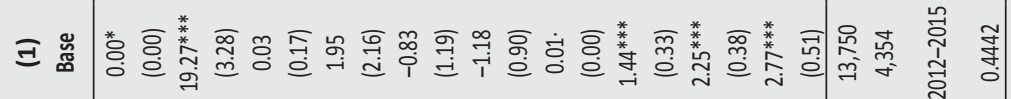

庹

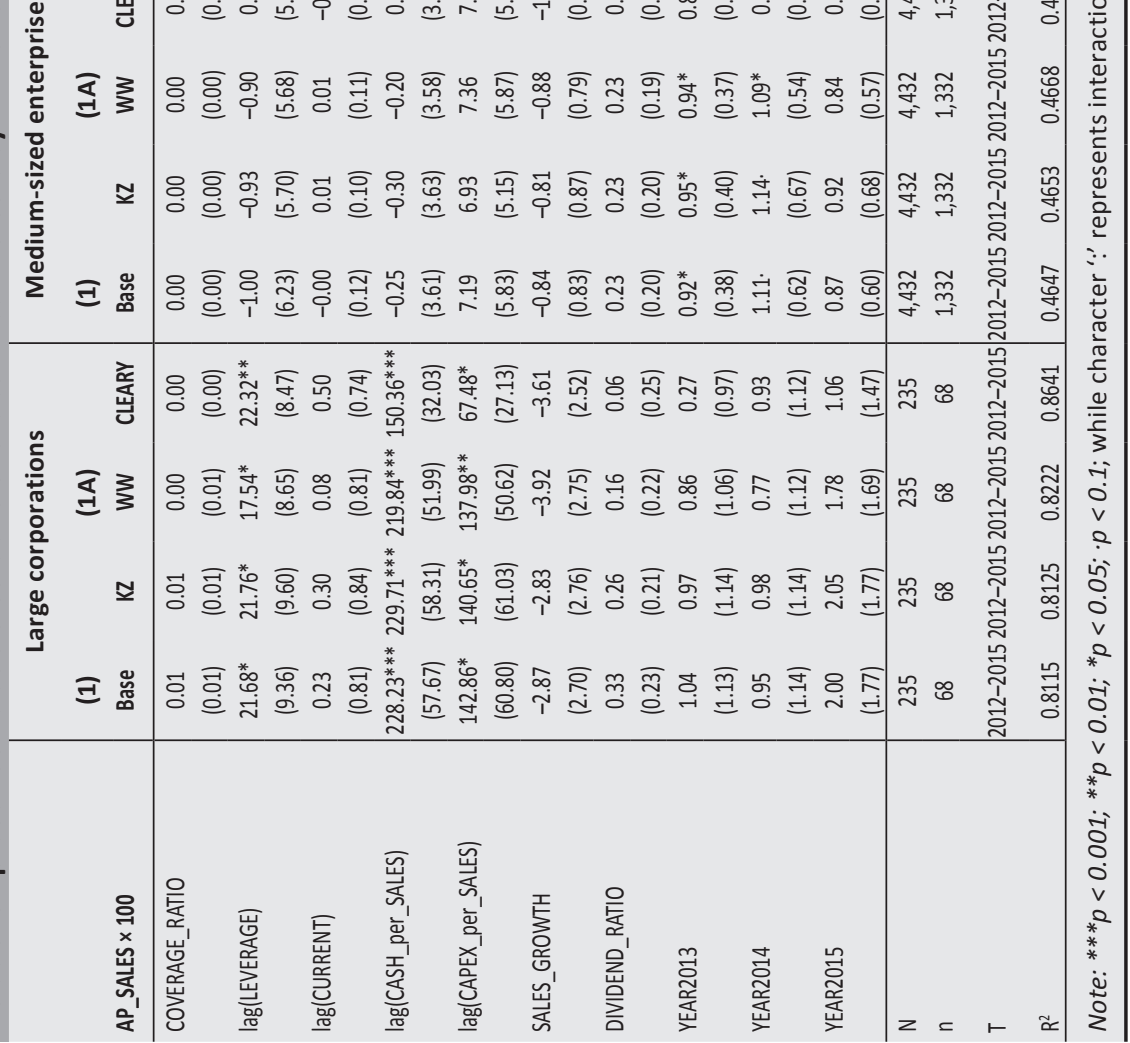


In terms of substitution, noteworthy features are identified by the analysis carried out on sub-samples by firm size, the results of which are reported in Table 8 . In the sub-sample of large corporations, the estimated coefficient of short-term loans is always negative. This implies substitution in the case of large corporations (regardless of whether they have become financially constrained according to the three indices). The model did not produce an estimate for the Whited-Wu interaction (presumably because only zero or one company is marked by the index as constrained), and the other two indices were found to be inconsistent. In this scenario, we should argue that the relationship between large corporations and banks is different from other cases, i.e. that often the size of large corporations makes it easier for them to use trade credit rather than bank credit, which represents the case of "medium wealth" in Burkart and Ellingsen's theory. In the category of medium and small enterprises, we found significant complementarity between bank credit and trade credit for financially unconstrained firms. The KZ and WW indices also failed on this sub-sample; only the interaction of the CLEARY dummy was significant. With microenterprises (which are presumably constrained in terms of both forms of funding), we found no correlation in firms where the bank constraint did not actually apply, and found complementarity in firms where it did. This scenario corresponds to the case of "low wealth" in Burkart and Ellingsen's model.

\section{Table 9}

\section{Summary of the results of sub-sample analyses}

\begin{tabular}{|c|c|c|c|}
\hline & \multicolumn{3}{|c|}{ Wealth (EBIT/ASSET) } \\
\hline & $\begin{array}{c}\text { Low }(<0 \%) \\
\text { (trade credit constraint } \\
\text { applies) }\end{array}$ & $\begin{array}{l}\text { Medium (0-14\%) } \\
\text { (no trade credit } \\
\text { constraint applies) }\end{array}$ & $\begin{array}{c}\text { High (>14\%) } \\
\text { (no trade credit } \\
\text { constraint applies) }\end{array}$ \\
\hline $\begin{array}{l}\text { In general } \\
\text { (where segmentation is } \\
\text { solely based on EBIT/ } \\
\text { ASSET) }\end{array}$ & $\begin{array}{c}\text { strong } \\
\text { complementarity* }\end{array}$ & complementarity & no correlation* \\
\hline $\begin{array}{l}\text { Constrained } \\
\text { (measured separately) }\end{array}$ & $\begin{array}{c}\text { strong } \\
\text { complementarity* }\end{array}$ & $\begin{array}{l}\text { complementarity* } \\
\text { (not robust) }\end{array}$ & $\begin{array}{c}\text { (the category is not } \\
\text { applicable to the model) }\end{array}$ \\
\hline \multirow[t]{3}{*}{$\begin{array}{l}\text { Unconstrained } \\
\text { (measured separately) }\end{array}$} & $\begin{array}{c}\text { (the category is not } \\
\text { applicable to the model) }\end{array}$ & $\begin{array}{c}\text { (the category is not } \\
\text { applicable to the model) }\end{array}$ & no correlation* \\
\hline & \multicolumn{3}{|c|}{ Firm size } \\
\hline & Micro & Small/Medium & Large \\
\hline Constrained & complementarity & $\begin{array}{l}\text { complementarity (not } \\
\text { robust) }\end{array}$ & substitution \\
\hline Unconstrained & no correlation & $\begin{array}{l}\text { complementarity } \\
\text { (not robust) }\end{array}$ & substitution \\
\hline
\end{tabular}

Note: In the upper part of the table, items marked with * indicate results that are consistent with the theory. 
Table 9 summarises the relationship between bank credit and trade credit on a case-by-case basis.

In the context of the empirical analysis, a few methodological limitations also emerged, in relation to which improvements may be appropriate in future research. It would be beneficial to construct the Kaplan-Zingales, Whited-Wu and Cleary indices on Hungarian data, and classify Hungarian firms on that basis. This would presumably produce more consistent estimates compared to our current results. Notwithstanding that, literature relying on US data is also divided over classification procedures. It is even uncertain whether average profitability can adequately capture the wealth variable used in the theoretical model. Although in prior investigations we arrived at similar results in breakdowns by other variables, we do not believe that an indicator consisting of a single component could be a good separator. The outcome was somewhat improved when firm size was also taken into account. For that reason, it could be appropriate to use the Burkart and Ellingsen's model to construct a trade credit constraint index on Hungarian data, which could be the Hungarian proxy for the model's "wealth" variable.

\section{Figure 2 \\ Development of unique effects over time}
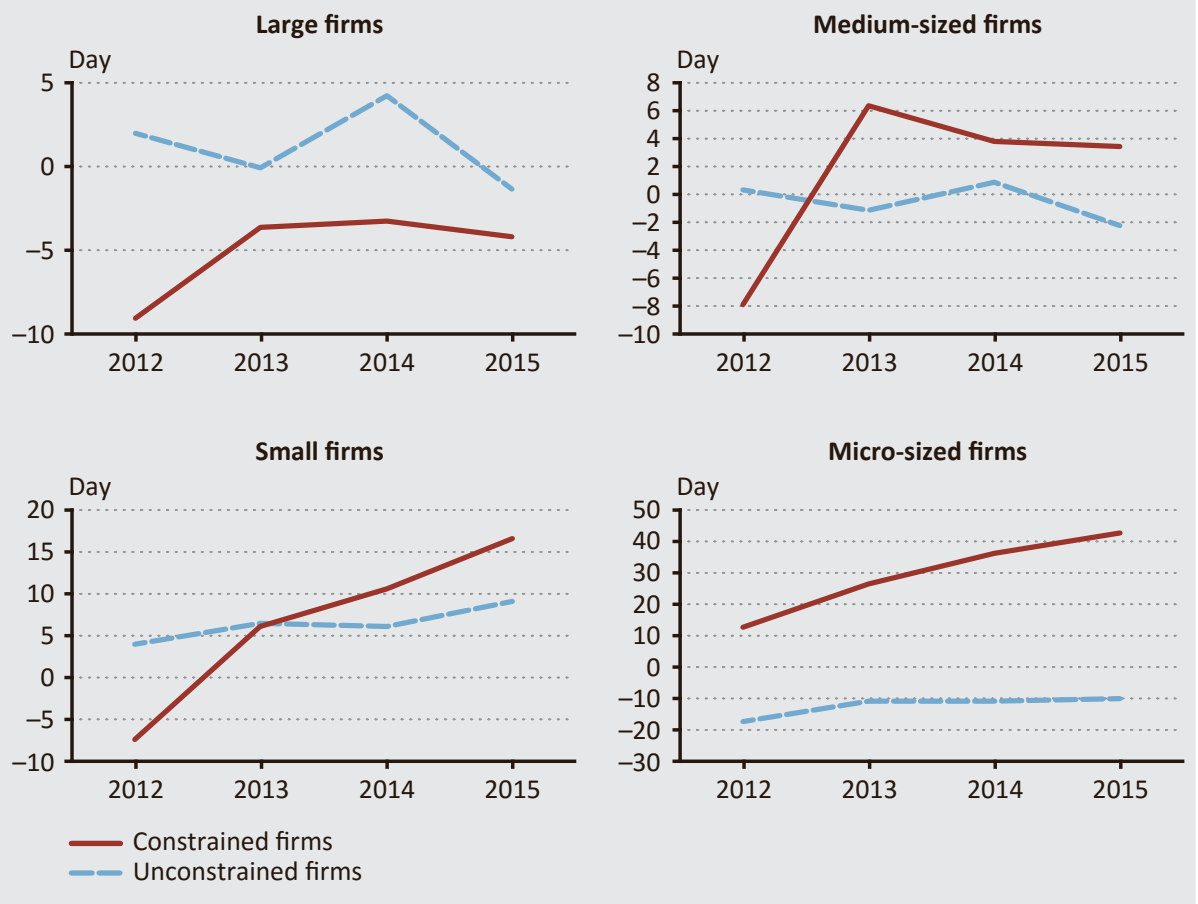
The trends of trade credit are addressed in our fourth analysis, which relates to Equation (2). Here we investigate the average development of days payable outstanding over time for financially constrained and financially unconstrained firms, adjusted for the unique (sector-specific, operational, etc.) characteristics of firms. By analysing the time effect, we wish to capture typical individual (nonaggregated) responses to cyclical developments, i.e. a behavioural pattern. The results of the estimation are reported in Table 10, and the parts related to cyclicality are illustrated in Figure 2.

\begin{tabular}{|c|c|c|c|c|}
\hline \multirow{2}{*}{ AP COST SALES $\times 365$} & \multicolumn{4}{|c|}{ (1A) } \\
\hline & Large & Medium & Small & Micro \\
\hline AR_SALES $\times 365$ & $\begin{array}{l}0.40 * * \\
(0.13)\end{array}$ & $\begin{array}{c}0.44^{* * *} \\
(0.12)\end{array}$ & $\begin{array}{c}0.56^{* * *} \\
(0.07)\end{array}$ & $\begin{array}{c}0.34^{* * *} \\
(0.03)\end{array}$ \\
\hline LOANS_ST_per_SALES & $\begin{array}{l}-19.17 \\
(30.11)\end{array}$ & $\begin{array}{c}170.07^{* * *} \\
(47.69)\end{array}$ & $\begin{array}{c}71.65^{* * *} \\
(19.32)\end{array}$ & $\begin{array}{c}33.26 * * * \\
(10.05)\end{array}$ \\
\hline LOANS_LT_per_SALES & $\begin{array}{c}87.99 \\
(136.89)\end{array}$ & $\begin{array}{l}191.95^{*} \\
(86.87)\end{array}$ & $\begin{array}{l}54.42 \\
(31.44)\end{array}$ & $\begin{array}{l}-3.46 \\
(10.89)\end{array}$ \\
\hline YEAR2013 & $\begin{array}{c}1.69 \\
(3.93)\end{array}$ & $\begin{array}{c}3.12 \\
(2.65)\end{array}$ & $\begin{array}{c}4.99 * * * \\
(1.46)\end{array}$ & $\begin{array}{l}5.06 \\
(2.88)\end{array}$ \\
\hline YEAR2014 & $\begin{array}{l}-2.79 \\
(3.74)\end{array}$ & $\begin{array}{c}4.19 \\
(3.54)\end{array}$ & $\begin{array}{c}6.83^{* * *} \\
(1.78)\end{array}$ & $\begin{array}{c}3.11 \\
(3.53)\end{array}$ \\
\hline YEAR2015 & $\begin{array}{c}1.92 \\
(4.63)\end{array}$ & $\begin{array}{l}-0.25 \\
(4.35)\end{array}$ & $\begin{array}{c}9.25^{* * *} \\
(2.46)\end{array}$ & $\begin{array}{c}3.67 \\
(3.77)\end{array}$ \\
\hline D.KZ.constr & $\begin{array}{l}-9.07^{*} \\
(4.53)\end{array}$ & $\begin{array}{l}-7.92 \\
(6.35)\end{array}$ & $\begin{array}{l}-7.43 \\
(4.84)\end{array}$ & $\begin{array}{l}12.21^{*} \\
(5.83)\end{array}$ \\
\hline D.KZ.unconstr & $\begin{array}{c}2.01 \\
(4.74)\end{array}$ & $\begin{array}{c}0.28 \\
(3.41)\end{array}$ & $\begin{array}{l}3.98 \\
(2.44)\end{array}$ & $\begin{array}{c}-17.42^{* * *} \\
(3.73)\end{array}$ \\
\hline YEAR2013:D.KZ.constr & $\begin{array}{c}3.74 \\
(5.66)\end{array}$ & $\begin{array}{l}11.07 \\
(6.56)\end{array}$ & $\begin{array}{l}8.51 \\
(4.64)\end{array}$ & $\begin{array}{c}8.62 \\
(5.42)\end{array}$ \\
\hline YEAR2014:D.KZ.constr & $\begin{array}{l}8.54 \\
(5.64)\end{array}$ & $\begin{array}{c}7.42 \\
(4.84)\end{array}$ & $\begin{array}{l}11.18^{*} \\
(4.65)\end{array}$ & $\begin{array}{c}20.35^{* *} \\
(6.83)\end{array}$ \\
\hline YEAR2015:D.KZ.constr & $\begin{array}{c}2.91 \\
(7.66)\end{array}$ & $\begin{array}{l}11.57 \\
(7.02)\end{array}$ & $\begin{array}{l}14.83^{*} \\
(6.94)\end{array}$ & $\begin{array}{c}26.36^{* *} \\
(9.17)\end{array}$ \\
\hline YEAR2013:D.KZ.unconstr & $\begin{array}{l}-3.73 \\
(5.45)\end{array}$ & $\begin{array}{l}-4.60 \\
(3.55)\end{array}$ & $\begin{array}{l}-2.58 \\
(2.06)\end{array}$ & $\begin{array}{c}1.67 \\
(4.03)\end{array}$ \\
\hline YEAR2014:D.KZ.unconstr & $\begin{array}{c}4.96 \\
(6.27)\end{array}$ & $\begin{array}{l}-3.62 \\
(3.46)\end{array}$ & $\begin{array}{c}-4.77^{*} \\
(2.30)\end{array}$ & $\begin{array}{c}3.62 \\
(4.50)\end{array}$ \\
\hline YEAR2015:D.KZ.unconstr & $\begin{array}{l}-5.29 \\
(5.90)\end{array}$ & $\begin{array}{l}-2.31 \\
(5.32)\end{array}$ & $\begin{array}{l}-4.20 \\
(2.83)\end{array}$ & $\begin{array}{c}3.40 \\
(4.82)\end{array}$ \\
\hline $\operatorname{lag}($ LOGASSET) & $\begin{array}{l}-6.79 \\
(4.12)\end{array}$ & $\begin{array}{c}-20.08^{* *} \\
(6.99)\end{array}$ & $\begin{array}{c}-31.20^{* * *} \\
(7.21)\end{array}$ & $\begin{array}{c}-19.82^{* * *} \\
(3.80)\end{array}$ \\
\hline EBIT_per_SALES & $\begin{array}{c}14.91 \\
(10.99)\end{array}$ & $\begin{array}{l}-23.91 \\
(16.35)\end{array}$ & $\begin{array}{c}-27.63^{*} \\
(10.97)\end{array}$ & $\begin{array}{l}-3.42 \\
(3.27)\end{array}$ \\
\hline
\end{tabular}




\begin{tabular}{|c|c|c|c|c|}
\hline $\begin{array}{l}\text { Table } 10 \\
\text { Estimation of the develc }\end{array}$ & t of days $p$ & ble outstar & g over tim & \\
\hline & & & & \\
\hline AP_COST_SALES $\times 365$ & Large & Medium & Small & Micro \\
\hline ROE & -6.79 & 5.70 & -4.80 & $7.14^{*}$ \\
\hline & $(4.16)$ & $(4.03)$ & $(4.18)$ & $(2.84)$ \\
\hline COVERAGE_RATIO & 0.01 & 0.01 & 0.01 & $0.01 *$ \\
\hline & $(0.01)$ & $(0.01)$ & $(0.00)$ & $(0.00)$ \\
\hline lag(LEVERAGE) & 30.72 & 3.05 & $59.10 * * *$ & 14.91 . \\
\hline & (18.66) & $(25.04)$ & (15.64) & (8.25) \\
\hline $\operatorname{lag}($ CURRENT) & 0.03 & 0.37 & 0.19 & $0.60 *$ \\
\hline & $(1.88)$ & $(0.57)$ & $(0.79)$ & $(0.27)$ \\
\hline lag(CASH_per_SALES) & $292.14^{* * *}$ & 1.81 & 18.86 & $6.27^{* *}$ \\
\hline & $(85.81)$ & (13.33) & $(9.76)$ & $(2.34)$ \\
\hline lag(CAPEX_per_SALES) & $222.38^{*}$ & 3.22 & -11.66 & -4.37 \\
\hline & (86.39) & $(40.23)$ & $(7.17)$ & $(3.46)$ \\
\hline SALES_GROWTH & -10.26 & -2.98 & -3.48 & $-8.09 * * *$ \\
\hline & $(6.06)$ & (3.58) & $(3.47)$ & $(1.62)$ \\
\hline DIVIDEND_RATIO & 0.54 & 0.82 & 0.02 & $-0.00 * * *$ \\
\hline & $(0.41)$ & $(0.73)$ & $(0.01)$ & $(0.00)$ \\
\hline$N$ & 235 & 4,432 & 13,739 & 24,000 \\
\hline$n$ & 68 & 1,332 & 4,352 & 8,790 \\
\hline $\mathrm{T}$ & $2012-2015$ & 2012-2015 & 2012-2015 & $2012-2015$ \\
\hline $\mathrm{R}^{2}$ & 0.7289 & 0.3613 & 0.2706 & 0.0748 \\
\hline
\end{tabular}

Note: ${ }^{* *} p<0.001 ;{ }^{* *} p<0.01 ;{ }^{*} p<0.05 ; \cdot p<0.1$; while character ' $:$ ' represents interaction between variables.

Although the estimation coefficients were not found to be statistically significant for large corporations and medium-sized enterprises, and thus the results are primarily applicable to small and microenterprises, all categories are represented. The diagrams are based on the average days payable outstanding in 2012 for unclassified firms. The diagrams show the differences relative to the base for each type.

Based on the estimated coefficients, days payable outstanding are found to have increased in financially constrained microenterprises. Between 2012 and 2013, a relatively moderate increase is also indicated for firms which are unconstrained according to their Kaplan-Zingales classification. The increase is also observed for constrained small enterprises, which implies pro-cyclical behaviour. By contrast, rather than an increase at a similar rate, stagnation is found for unconstrained firms. 


\section{Summary}

This paper investigates the role of trade credit in Hungarian non-financial, non-utility firms that submit annual accounts prepared in Hungarian forints. In 2010-2015, firms initially faced difficulties in accessing finance and then benefited from the easing of terms. In this study, we sought to determine how firm's use of trade credit was related to their use of bank credit. For our empirical analysis, we relied on Burkart and Ellingsen's (2004) theory. Although it was only possible to partially confirm the theory, some findings of practical relevance were made beyond the scope of the theory on the basis of our data. On the entire sample, we found shortterm loans and accounts payable to be complementary, the effect of which was stronger in firms that better exploited their capacity for bank debt. For firms with low own funds (equivalent to low wealth in Burkart and Ellingsen's model and a low $\mathrm{EBIT} /$ Sales ratio in the statistical analysis), we found strong complementarity, while no substitution could be demonstrated for highly profitable firms. We repeated the analysis in a breakdown by firm size, which indicated substitution in the category of large corporations. Although firm size cannot be considered as a proxy for wealth, we thought it important to document the differences in the other size categories as well. In the paper, primarily for illustration purposes, we also represented the trend of trade credit over time in a breakdown by size, and found that in the period of improving finance, the role of trade credit became more prominent in financially constrained firms, and remained level in unconstrained firms.

\section{References}

Bálint, M. - Fellner, Z. (2016): Hitelezési folyamatok - 2016. augusztus (Trends in Lending - August 2016). https://www.mnb.hu/kiadvanyok/jelentesek/hitelezesi-folyamatok/ hitelezesi-folyamatok-2016-augusztus. Downloaded: 8 August 2017.

Bálint, M. - Fellner, Z. (2017): Hitelezési folyamatok - 2017. május (Trends in Lending May 2017). https://www.mnb.hu/kiadvanyok/jelentesek/hitelezesi-folyamatok/hitelezesifolyamatok-2017-majus. Downloaded: 8 August 2017.

Biais, B. - Gollier, C. (1997): Trade credit and credit rationing. The Review of Financial Studies, 10(4): 903-937. https://doi.org/10.1093/rfs/10.4.903

Bokor, Cs. - Fellner, Z. - Plajner, Á. (2014): The use and expected impact of loans taken out in the Funding for Growth Scheme - results of a questionnaire-based survey. In: MNB (2014): The Funding for Growth Scheme - The first 18 months, MNB. https://www.mnb. hu/letoltes/nhp-tanulmanykotet-eng-b5-digit.pdf. Downloaded: 8 August 2017. 
Bougheas, S. - Mateut, S. - Mizen, P. (2007): The inventory channel of trade credit: Theory and Evidence. Working Paper. Department of Economics, University of Sheffield. ISSN 1749-8368.

Brennan, M. - Maksimovic, V. - Zechner, J. (1988): Vendor financing. The Journal of Finance, 43(5): 1127-1141. https://doi.org/10.1111/j.1540-6261.1988.tb03960.x

Burkart, M. - Ellingsen, T. (2004): In-kind finance: a theory of trade credit. American Economic Review, 94(3): 569-590. https://doi.org/10.1257/0002828041464579

Chittenden, F. - Bragg, R. (1997): Trade credit, cash-flow and SMEs in the UK, Germany and France. International Small Business Journal, 16(1): 22-35. https://doi. org/10.1177/0266242697161002

Cleary, S. (1999): The relationship between firm investment and financial status. The Journal of Finance, 54(2): 673-692. https://doi.org/10.1111/0022-1082.00121

Csubák, T.K. - Fejes, J. (2014): A magyar kkv-k 21. századi banki finanszírozásának áttekintése és kiútkeresés a hitelválság csapdájából (Overview of bank financing for Hungarian SMEs in the 21st century, and the search for and escape from the debt trap). Financial and Economic Review, 13(2): 174-194.

Cunningham, R.M. (2005): Trade credit and credit rationing in Canadian firms. Bank of Canada Working Paper, No. 2004-49. https://doi.org/10.2139/ssrn.643023

Elsas, R. - Klepsch, C. (2016): How and when do firms adjust their investments toward targets? https://dx.doi.org/10.2139/ssrn.2775091

Endrész, M. - Harasztosi, P. - Lieli, R. (2015): The Impact of the Magyar Nemzeti Bank's Funding for Growth Scheme on Firm Level Investment. MNB Working Papers 2. https:// www.mnb.hu/letoltes/ehl-wp-2015-final-1.pdf. Downloaded: 8 August 2017.

Emery, G.W. (1984): A pure financial explanation for trade credit. Journal of Financial and Quantitative Analysis, 19(3): 271-285. https://doi.org/10.2307/2331090

Fazzari, S.M. - Petersen, B.C. (1993): Working capital and fixed investment: new evidence on financing constraints. The RAND Journal of Economics, 24(3): 328-342. http://www. jstor.org/stable/2555961

Farre-Mensa, J. - Ljungqvist, A. (2016): Do measures of financial constraints measure financial constraints? The Review of Financial Studies, 29(2): 271-308. https://doi. org/10.1093/rfs/hhv052

Ferrando, A. - Mulier, K. (2013): Do firms use the trade credit channel to manage growth? Journal of Banking \& Finance, 37(8): 3035-3046. https://doi.org/10.1016/j. jbankfin.2013.02.013 
Ferris, J.S. (1981): A transactions theory of trade credit use. The Quarterly Journal of Economics, 96(2): 243-270. https://doi.org/10.2307/1882390

Freixas, X. (1993): Short-term credit versus account receivable financing. Economics Working Paper 27. Department of Economics and Business, Universitat Pompeu Fabra. https:// ideas.repec.org/p/upf/upfgen/27.html

García-Teruel, P.J. - Martínez-Solano, P. (2010): Determinants of trade credit: A comparative study of European SMEs. International Small Business Journal, 28(3): 215-233. https:// doi.org/10.1177/0266242609360603

Juhász, P. - Reszegi, L. (2017): Gátak a magyar vállalati növekedésben (Barriers to Hungarian Corporate Growth). Vezetéstudomány, 48(6-7): 27-38.

Kaplan, S.N. - Zingales, L. (1997): Do investment-cash flow sensitivities provide useful measures of financing constraints? The Quarterly Journal of Economics, 112(1): 169-215. https://doi.org/10.1162/003355397555163

Kling, G. - Paul, S.Y. - Gonis, E. (2014): Cash holding, trade credit and access to short-term bank finance. International Review of Financial Analysis, Vol. 32(March): 123-131. https:// doi.org/10.1016/j.irfa.2014.01.013

MNB (2015): Time series of credit institutions limited by shares (ended 31.12.2014). https:// www.mnb.hu/felugyelet/idosorok/i-penz-es-hitelpiaci-szervezetek. Downloaded: 7 August 2017.

MNB (2017): Financial Stability Report (May 2017). https://www.mnb.hu/en/publications/ reports/financial-stability-report/financial-stability-report-may-2017. Downloaded: 8 August 2017.

Módos, D. - Bokor, Cs. - Hidasi, B. (2014): Main features of FGS loans and companies borrowing under the scheme. In: MNB (2014): The Funding for Growth Scheme - The first 18 months, MNB. https://www.mnb.hu/letoltes/nhp-tanulmanykotet-eng-b5-digit. pdf. Downloaded: 8 August 2017.

Nábelek, F. (2016): Késedelmes fizetés a magyar vállalkozások körében (Overdue payment among Hungarian firms). Institute for Economic and Enterprise Research. http://gvi.hu/ kutatas/467/kesedelmes_fizetes_a_magyar_vallalkozasok_koreben

Nilsen, J.H. (2002). Trade credit and the bank lending channel. Journal of Money, Credit, and Banking, 34(1): 226-253. https://doi.org/10.1353/mcb.2002.0032

Nyírő, Zs. - Hajdu, M. (2015): A GVI 2015. januári KKV Körkép felvételének eredményei (Evidence from the GVI SME Survey of January 2015). Institute for Economic and Enterprise Research. http://gvi.hu/kutatas/398/kkv_korkep_2015_januar_javulo_uzleti_varakozasok_a_kkv_ szektorban 
Petersen, M.A. - Rajan, R.G. (1997): Trade credit: theories and evidence. Review of Financial Studies, 10(3): 661-661. https://doi.org/10.1093/rfs/10.3.661

SAFE (2011): 2011 SMEs' access to finance. Survey. Analytical Report. European Commission, Enterprise and Industry. http://ec.europa.eu/DocsRoom/documents/7922/attachments/1/ translations/en/renditions/native. Downloaded: 8 August 2017.

SAFE (2013): 2013 SMEs' access to finance. Survey. Analytical Report. European Commission, Enterprise and Industry. http://ec.europa.eu/docsroom/documents/7864/attachments/1/ translations/en/renditions/native. Downloaded: 8 August 2017.

SAFE (2014): Survey on the access to finance of small and medium-sized enterprises in the euro area, October 2013 to March 2014. European Central Bank. https://www.ecb. europa.eu/pub/pdf/other/accesstofinancesmallmediumsizedenterprises201404en.pdf. Downloaded: 8 August 2017.

SAFE (2015): Survey on the access to finance of enterprises (SAFE). Analytical Report 2015. European Commission. http://ec.europa.eu/DocsRoom/documents/14321/attachments/1/ translations/en/renditions/native. Downloaded: 8 August 2017.

Schwartz, R.A. (1974): An economic model of trade credit. Journal of Financial and Quantitative Analysis, 9(4): 643-657. https://doi.org/10.2307/2329765

Smith, J.K. (1987): Trade credit and informational asymmetry. The Journal of Finance, 42(4): 863-872. https://doi.org/10.1111/j.1540-6261.1987.tb03916.x

Szűcs, N. (2008): Lánctartozás a kereskedelmi hitelezés irodalmának tükrében (Circular debt as reported in the literature on trade credit). Financial and Economic Review, 7(4): 399-417.

Whited, T.M. - Wu, G. (2006): Financial constraints risk. Review of Financial Studies, 19(2): 531-559. https://doi.org/10.1093/rfs/hhj012

Ying, Q. - Guo, W. - Yang, T. (2014): The substitution effect of trade credit financing in an emerging economy: empirical evidence from China. In: Xu, J. - Cruz-Machado, V. - Lev, B. - Nickel, S. (eds.): Proceedings of the Eighth International Conference on Management Science and Engineering Management. Advances in Intelligent Systems and Computing, vol. 280, Springer, Berlin, Heidelberg, pp. 551-561. http://doi.org/10.1007/978-3-64255182-6_48 